\title{
The Early History of the Multiple Sclerosis Society of Great Britain and Northern Ireland: A Socio-Historical Study of Lay/Practitioner Interaction in the Context of a Medical Charity
}

\author{
MALCOLM NICOLSON and GEORGE W LOWIS*
}

In the twentieth century single-disease charities have become an established feature of the social organization of biomedicine, providing support and welfare for sufferers and raising funds for research. Such charities are an important interface between the medical profession and the interested laity. They therefore constitute a subject area that ought to reward the attention of the historian or sociologist of medicine. ${ }^{1}$ The present paper approaches the issue of lay/professional interaction within recent biomedicine through an investigation of the early history of the Multiple Sclerosis Society of Great Britain and Northern Ireland. ${ }^{2}$ We explore episodes in the development of the Society from its foundation in 1953 to the retirement of its founder-chairman in 1976.

\footnotetext{
* Dr Malcolm Nicolson, Centre for the History of Medicine, University of Glasgow. Professor George W Lowis, Department of Epidemiology and Public Health, University of Miami. Address for correspondence: Dr Malcolm Nicolson, 5 University Gardens, University of Glasgow, Glasgow, G12 8QQ.

E-mail wellmn@arts.gla.ac.uk
}

Dr Nicolson has been supported by the Wellcome Trust, to whom he wishes to record his thanks, throughout the course of his work on this paper. Professor Lowis was the grateful recipient of a Wellcome Trust grant in aid of research expenses in 1996. We have benefited immensely from conversations with a number of members and associates of the MS Society. Nicolson would like to thank Lesley Hall for bringing the Wellcome Library's holding of Cave's papers to his attention.

${ }^{1}$ Little work has however been done in this area. For an exemplification of its potential, see
M-A Bach, 'Building the French Muscular Dystrophy Association: the role of doctor/patient interactions', Soc. Hist. Med., 1998, 11: 233-53. For background, see W F Bynum, 'Medical philanthropy after 1850', in W F Bynum and R Porter (eds), Companion encyclopedia of the history of medicine, vol. 2, London, Routledge, 1993, pp. 1480-94.

${ }^{2} \mathrm{~A}$ major source for the history of the Society is the substantial collection of the papers of Richard Cave, which is held in the Wellcome Library, Archives and Manuscripts, shelf mark SA/MSS. All unpublished material referred to below is from this collection unless otherwise stated. Individual items are identified by their file numbers; see L Hall, 'Multiple Sclerosis Society of Great Britain and Northern Ireland: list of papers in the Contemporary Medical Archives Centre at the Wellcome Institute for the History of Medicine', unpublished catalogue. 


\section{Malcolm Nicolson and George $W$ Lowis}

Multiple sclerosis (MS) is a chronic disease which is marked by progressive impairment of the nervous system. ${ }^{3}$ The first manifestations of the disease generally occur in early adulthood. Prognosis is very uncertain but the development of multiple sclerosis tends to be slow and inconstant. ${ }^{4}$ Many sufferers experience quite long periods of spontaneous remission between attacks. The cause of multiple sclerosis is not known. There is no recognized cure. A very large number of therapeutic procedures have, however, been claimed to have some beneficial effects in the treatment of MS. ${ }^{5}$

Unlike sufferers from cancer or the chronic diseases of childhood or old age, MS patients are often relatively young, active, articulate individuals with sufficient energy, time and motivation to take a close interest in medical and scientific attitudes towards their disease. Thus, many of the active members of the MS Society are sufferers from multiple sclerosis. ${ }^{6}$ Another substantial portion of the Society's membership consists of familial carers of MS patients. The MS Society is, therefore, a particularly interesting locus of lay/professional interaction in the biomedical sphere.

Much recent sociological work on chronic illness has been person-centred, focusing upon the impact of ill-health upon life expectations, career plans, relationships, self image, and so forth. ${ }^{7}$ For multiple sclerosis such studies have indeed been very informative. ${ }^{8}$ But, chronic illness may also be understood by a focus on more collective activities and concerns, such as are revealed in the course of participation in charitable societies and self-help groups. The history of attitudes towards, and among, sufferers from multiple sclerosis also provides insights into the changing place of the chronically ill and the disabled in mid-twentieth-century British society more generally. For reasons we will explore, much of the early history of the Multiple Sclerosis Society was turbulent. A study of some of the controversies which marked

\footnotetext{
${ }^{3}$ For an authoritative medical account of multiple sclerosis, see A Compston et al., McAlpine's multiple sclerosis, 3rd ed., Edinburgh, Churchill Livingstone, 1998. For an epidemiological overview, G C Ebers, 'The geographic distribution of multiple sclerosis: a review', Neuroepidemiology, 1993, 12: 1-5.

${ }^{4}$ For an account of the psycho-social problems associated with the uncertainty of prognosis, see I Robinson, Multiple sclerosis, London, Routledge, 1988, pp. 36-40; I Robinson, A Lawson and A Wynne, Talking about $M S$, general report no. 1, Brunel-ARMS Research Unit, University of West London, 1983; F Davis, 'Uncertainty in medical prognosis, clinical and functional', Am. J. Sociol., 1961, 66: 41-7.

${ }^{5}$ Editorial, “"Cures" for multiple sclerosis', $\mathrm{Br}$. med. J., 1970, i: 59-60. W A Sibley, Therapeutic claims in multiple sclerosis, New York, Demos/ Vermande, 1998.

' It is the authors' impression, and that of several of the members we spoke to, that the MS
}

Society has a greater proportion of active sufferer members than most other single-disease charities. But quite how typical the MS Society is in this and other aspects of its organization remains a matter for further research.

${ }^{7}$ For example, M R Bury, 'Chronic illness as biographical disruption', Sociol. Health Illn., 1982, 4: 167-82; R Anderson and M R Bury (eds), Living with chronic illness, London, Unwin Hyman, 1988.

${ }^{8}$ I Robinson, 'Personal narratives, social careers and medical courses: analysing life trajectories in autobiographies of people with multiple sclerosis', Soc. Sci. Med., 1990, 30: 1173-86; J Monks and R Frankenburg, 'Being ill and being me: self, body and time in multiple sclerosis narratives', in B Ingstad and S R Whyte (eds), Disability and culture, Berkeley and Los Angeles, University of California Press, 1995, pp. 107-33. 
its development reveals much about the social tensions that existed within British biomedicine throughout the $1950 \mathrm{~s}, 60 \mathrm{~s}$ and $70 \mathrm{~s}^{9}{ }^{9}$

\section{The History of the MS Society}

The Multiple Sclerosis Society of Great Britain and Northern Ireland was founded in 1953, by Richard Cave, a member of the senior legal staff of the House of Lords, whose wife suffered from the disease. ${ }^{10}$ One of Cave's first actions as founder was to recruit medical advisors for the Society. Such advisory committees are a standard adjunct to medical charities in Britain. ${ }^{11}$ Cave secured the services of one of the doctors who had treated his wife, Douglas McAlpine, consultant neurologist at the Middlesex Hospital. ${ }^{12}$ Cave was later to recall that at one stage the Multiple Sclerosis Society consisted only of himself and Dr McAlpine. ${ }^{13}$ McAlpine proceeded to recruit some of his senior neurological colleagues to form a Medical Panel. Thus, from its very beginnings the MS Society had very close yet deferential links with the upper echelons of the medical profession and in particular with the speciality of neurology. The nature of this relationship was made explicit in the Society's constitution-rule 24 of which stated:

The maintenance of a strictly ethical relationship with the Medical Profession is a cardinal point of the Society's policy. It follows that the Society cannot under any circumstances express publicly, or to its members, any opinion on the efficacy of treatments or so-called "cures", as this must be the prerogative of the Medical Profession. ${ }^{14}$

Even such professed subservience did not, however, prevent the Society regularly being criticized by doctors. ${ }^{15}$ There was, as we shall see, much general antagonism toward the single-disease charities, and indeed toward any lay involvement in medical matters, amongst members of the medical profession at this time. Cave was fortunate that he had chosen, in McAlpine, a man who was famous for his independence of mind (and income). To be prominently involved with a lay society required a degree of moral courage on behalf of a consultant physician in the 1950s. But even McAlpine would sometimes feel it necessary to protect himself against possible criticism by his peers.

\footnotetext{
${ }^{9}$ While, as historians, we are particularly interested in controversies and what they reveal, such a perspective does not preclude an appreciation of the many concrete achievements of the MS Society in both the welfare and research spheres.

${ }^{10}$ For biographical details of Cave, see $G$ Howell, 'Profile of Richard Cave-Founder and Chairman', MS News, 1965, Autumn, 6-9.

${ }^{11}$ That applications for research funds are peer-reviewed is the most important criterion for membership of the Association of Medical

Research Charities, which was founded in 1972, see Bynum, op. cit., note 1 above.

${ }^{12}$ For biographical details of McAlpine, see $J$ Walton, 'McAlpine, (Archibald) Douglas
}

1890-1981', Dictionary of national biography, Oxford University Press, 1990. McAlpine was the principal author of the definitive textbook, D McAlpine, N D Compston, C E Lumsden, Multiple sclerosis, Edinburgh, Livingstone, 1955.

${ }^{13}$ Letter, R Cave to D McAlpine, 22 Nov. 1967, in SA/MSS/B.19.

14 'Rules for Branches and Groups', 3 July 1957, in SA/MSS/A.13. Cave often quoted this section of the constitution when defending the Society against accusations of impropriety, for example, letter, $\mathrm{R}$ Cave to Lord Brain, 22 May 1963, SA/MSS/A.12.

${ }^{15}$ See, for example, letter, E R Bickerstaff to A C Waine, 24 Sept. 1969, SA/MSS/A.12. 


\section{Malcolm Nicolson and George W Lowis}

To a significant extent, the Society's deferential relationship with the medical establishment only mirrored its more general social characteristics. Cave utilized the contacts he enjoyed due to his position in the Palace of Westminster to assemble a very distinguished group of patrons, president and vice-presidents for the Society. He seems to have relished this aspect of his activities as founder. ${ }^{16}$ Cave was also Secretary of the Association of Lieutenants of Counties, from within whose ranks he regularly recruited aristocratic or genteel presidents for the various regional branches of the Society, as they were set up. The MS Society was thus from its inception a creature of the more exclusive strata of British public life. Its sponsors were drawn from the noble, the great and the good. Its policy-making and executive hierarchies were, often literally, of the officer class. ${ }^{17}$ At least in its early years, the Society derived much of its character from taken-for-granted patterns of authority and deference. It was devised so as to provide charity along the traditional British lines of hierarchical patronage and gracious condescension.

Richard Cave was, moreover, a devout Roman Catholic-he was indeed one of Britain's leading Catholic laymen. ${ }^{18}$ His religious commitment undoubtedly influenced his conception of the Society's purpose. It was to be a vehicle for dispensing Christian charity, providing material, and especially spiritual, comfort to MS sufferers and their families. He devoted much time to organizing special religious services for MS sufferers, some of them in Westminster Cathedral, as well as running regular pilgrimages to Lourdes. ${ }^{19}$ Cave often spoke of multiple sclerosis as if it were a gift of the Holy Ghost:

We are all members of the Mystical Body of Christ ... and are called upon ... to make reparation for the evil which has characterized the world since the beginning of time. This being so, how great is the opportunity which God gives his invalid in sharing in the suffering that is necessary for our salvation. When we reflect that Christ Himself suffered to an extent which we can hardly imagine, we can see that those who are stricken with MS ... may well be specially favoured by God in that their lives, by their sufferings and by their lack of worldly advantages, follow the pattern of Our Lord's life. ${ }^{20}$

It was, moreover, not only MS sufferers who might, in Cave's view, be specially favoured. Under the auspices of the Society, Cave organized residential training courses for the relatives of MS patients. His address to the first of these courses ended on an uplifting note:

The truth is that we are all called to be saints. The saints all started as ordinary men and women. What distinguished them was the fact that, for the love of God, they did ordinary things extraordinarily well ... When we are carrying a bedpan, or feeding someone through

\footnotetext{
${ }^{16}$ See file SA/MSS/A.29.

${ }^{17}$ Captain Ludovic Porter, R.N., was the first Organising Secretary of the Society, serving until 1966. (He was succeeded by A C Waine, who had the title General Secretary.) Major Guy

Armstrong, R.A., was the influential chair of the Policy Subcommittee. A number of other military titles will be noted below.

${ }^{18}$ Cave was created a Papal Knight of St

Gregory the Great in 1966; Anon, 'Editorial', $M S$
}

News, 1967, Spring, 1. He was a close friend of Archbishop, later Cardinal, Hume; see file SA MSS/A.46.

${ }^{19}$ See file SA/MSS/A.30.

${ }^{20}$ R Cave, 'Why Sickness?', Newsletter, Hull and East Riding Branch, Multiple Sclerosis Society, undated [probably late 1957], 2-3. Also published in $M S$ News, 1958, Spring, 4-5, and elsewhere. 


\section{The Early History of the Multiple Sclerosis Society}

a straw, or doing the other mundane and sometimes nauseating jobs which fall to our lot, we probably feel very far from sanctity. But we shouldn't feel so, because in doing these jobs willingly and uncomplainingly, we are carrying out Our Lord's direct command ... Many people spend a lifetime searching for God's will. We, the relatives of MS patients, are specially favoured, favoured above those who in the eyes of the world are more happily placed. For us, God's Will is plain; the ladder of perfection is placed at our feet for us to make use of. I suggest that we can finish this course in no better way than by paying a visit to one of the two chapels here ... and there praying for Grace ... to accept willingly our own particular cross. $^{21}$

As we shall see, not all the membership of the Society were able to regard the problems associated with MS with this degree of fortitude and patient reconciliation. ${ }^{22}$

We can discern, therefore, in the original characteristics of the Society the germs of much of its future troubles. It devolved a major part of its authority and decisionmaking to an exclusive and self-perpetuating group of medical advisors, who were not answerable to the membership as a whole, who indeed were never identified, save for a discreet listing in the Annual Report. Even Cave seems not to have known very much about the workings of the Society's medical committees. ${ }^{23}$ In the other spheres of the Society's activity, power structures were equally hierarchical. The General Council, its principal governing body, was originally formed by Cave's invitation. As vacancies occurred, they were filled either by co-option or by interviewing from a list of nominated candidates. The Council could and did refuse even to interview candidate members whom it considered unsuitable. The founders of the Society took for granted deference on behalf of the rank-and-file members towards the magic circle of the great and good at the top.

Cave's initial intentions for the Society, dominated as they were by concerns for material support and spiritual comfort, seem not to have included the sponsorship of scientific research. In an editorial in the inaugural issue of MS News, the Society's newsletter, he stated that, "First and last, the Multiple Sclerosis Society exists to

\footnotetext{
${ }^{21} \mathbf{R}$ Cave, 'Closing address at the first Multiple Sclerosis Society course for Relatives held at Le Court Study Centre, Liss, Hants, 8th12th December, 1969', typescript, SA/MSS/A.28. Le Court was a Cheshire Home, many of the residents of which were multiple sclerosis patients, and Cave would seem to have been very influenced by the spiritual and welfare ethos of the Cheshire Foundation. He and Group Captain Cheshire were close friends, see SA/MSS/A.28. It is interesting, moreover, that Le Court was riven by tensions between the chronic sick and their carers that were not dissimilar to those experienced by the MS Society, see E J Miller and G V Gwynne, A life apart, London, Tavistock, 1972. Cave also maintained active links, on behalf of the MS Society, with a number of other religious charities.
}

\footnotetext{
${ }^{22}$ This is not to deny that religious consolations are very important to many MS sufferers, see Robinson, op. cit., note 4 above, on pp. 131-4.

${ }^{23}$ As late as the mid-sixties, Cave had to quiz Professor Henry Miller, then Chair of the Medical Panel, at some length to discover, on behalf of the Society, exactly how the MARC was constituted. Letter, R Cave to H Miller, 9 Dec. 1965, SA/MSS/B.20: 'Perhaps I might pose some propositions and questions: 1) Presumably the M.A.R.C. is a committee appointed in the first place by the Medical Panel? Do all members of the Medical Panel receive minutes of the meetings of the M.A.R.C.?' And so on, for two detailed pages.
} 


\section{Malcolm Nicolson and George W Lowis}

help MS patients", ${ }^{24}$ no mention being made of the direct funding of research. In the first year or two of its existence, the Society spent its disposable monies mainly on the welfare of MS patients and their families. In 1954, the policy of the Society would seem to have been to seek to stimulate research indirectly by increasing awareness of multiple sclerosis among scientists, the Government and the general public. ${ }^{25}$

In not seeking to fund research projects, the Society was following the explicit recommendation of McAlpine and the Medical Panel. ${ }^{26}$ This cautious advice reflected the antipathy of the British medical establishment at that time toward active lay involvement in medical matters. Similar views prevailed in Government circles. Both the Lord President of the Council and the Minister of Health (Iain Macleod) actively discouraged the Society from taking on a direct role in the funding of basic research, wishing no doubt to reserve a monopoly of such operations for the Medical Research Council (MRC). ${ }^{27}$ In an address to the inaugural meeting of the Society, Macleod stressed his support for the work of the Society "in the field of rehabilitation and education". ${ }^{28}$

Cave knew, however, of the research funding activities of the American and Canadian MS Societies, and was increasingly conscious also of the aspirations of the growing numbers of ordinary members of the Society. ${ }^{29}$ By April 1955, he had become convinced that sponsoring research should indeed be a major aspect of the Society's activities. ${ }^{30}$ Sir Harold Himsworth, Secretary of the MRC, was more encouraging than his political colleagues ${ }^{31}$ and suggested that the Society consider providing funds to equip a new laboratory for Charles Lumsden, who had recently been appointed Professor of Pathology at Leeds. ${ }^{32}$ By a coincidence Lumsden was a member of the MS Society's Medical Panel and a close friend and ally of McAlpine. The Society duly made a grant of $£ 10,000$ pounds to Lumsden in August $1955 .^{33}$

The sponsorship of Lumsden notwithstanding, the Policy Subcommittee of the MS Society still felt, in 1956, that "the drive for research [was] still a rather nebulous hope for the future" and that the Society should not be distracted from its primary purpose of providing "positive help for MS sufferers". ${ }^{34}$ Even operating under this somewhat narrowly defined remit, however, the Society could not avoid involvement in controversial medical matters. In the mid-fifties there was a brief flurry of interest

\footnotetext{
${ }^{24} \mathrm{R}$ Cave, 'Editorial', MS News, 1954, 1:1.

${ }^{25}$ Multiple Sclerosis Society, Policy

Subcommittee, 'Summary of Recommendations, 20th Sept 1955', SA/MSS/A.44.

${ }^{26}$ Annual report of the Multiple Sclerosis Society of Great Britain and Northern Ireland, 1954.

${ }^{27}$ Multiple Sclerosis Society, Policy

Subcommittee, 'Recommendations for disposal of Agnes Wood Fund', SA/MSS/A.44.

${ }^{28}$ I Macleod, 'Message', MS News, 1954, 1:1.

${ }^{29}$ Letter, Chris [no surname] to R Cave, 22 March 1955, SA/MSS/A.7.
}

\footnotetext{
${ }^{30}$ Letter, R Cave to R C Rose, 21 April 1955, SA/MSS/A.7; Letter, R Cave to E Gowers, 31 March 1955, SA/MSS/A.7.

${ }^{31}$ Himworth's support was offered in the face of the opposition of his senior colleagues in the MRC, see letter, L Porter to R Cave, 18 March [no year given], SA/MSS/B.13.

${ }^{32}$ Letter, H Himsworth to R Cave, 29 June 1956, SA/MSS/A.44.

${ }^{33}$ MS Society, Policy Subcommittee, 'Notes', 24 Aug. 1955, SA/MSS/A.44.

${ }^{34}$ MS Society, Policy Subcommittee, 'Programme for 1955/56', SA/MSS/A.44.
} 
in the vaccine therapies of Dr William M Crofton..$^{35}$ The possibility of therapeutic vaccines had attracted considerable attention in the early decades of the century but ${ }^{*}$ the idea had been virtually entirely discredited and abandoned long before the Second World War. ${ }^{36}$ Crofton, however, remained an advocate. He maintained that multiple sclerosis was a virus disease which, together with a number of similar infectious disorders, could yield to vaccine treatment. His views on MS received widespread publicity when they were aired in the House of Lords in April 1955, in the course of a debate on foot-and-mouth disease, by Lord Brabazon of Tara. Lord Brabazon called for an official investigation of Crofton's claims and a "rewriting of all the bacteriological textbooks". ${ }^{37}$

Following Brabazon's intervention, the MS Society received many letters from its members, inquiring about the putative therapy. Cave sought the advice of his Medical Panel. McAlpine replied:

I have spoken to the Medical Defence Union. The Secretary advises that if the M.S.S. intend to send a reply to letters regarding this vaccine it should seek the advice of Counsel. Furthermore the Defence Union would like to see a copy of any letter ... before it is sent out. ${ }^{38}$

In other words, McAlpine was reminding Cave of the legal prerogatives and privileges which the orthodox medical profession enjoyed. The Defence Union would be prepared to take action to preserve the profession's legal monopoly, if need be. Taking heed of McAlpine's warning, the Society prepared the following standard reply:

Thank you very much for your letter of ... and I can understand your interest in Lord Brabazon's statement in the House of Lords. Unfortunately this Society is unable to comment on the effectiveness of Dr Crofton's treatment, as we cannot usurp medical prerogative ... the best I can do for you is to advise you to consult your Doctor and be guided by him in the treatment you undertake. ${ }^{39}$

This action did not end the Society's problems with Crofton, however. Later in the year, Mr Victor Bennett, an MS patient, asked the Society for help with transport to enable him to consult Crofton. The provision of transport for MS patients was a routine welfare activity of the Society. Bennett's request was, however, refused. $\mathrm{He}$ was not pleased and wrote to tell the Society so. Bennett's complaint contains an interesting personal assessment of the character of the MS Society and accurately prefigures the nature of some of its later difficulties:

\footnotetext{
${ }^{35}$ William Mervyn Crofton (b. 1879) was a pathologist by training. Having been pathologist to St Stevens Hospital, Dublin, and a lecturer in pathology at University College, Dublin, he set himself up, in the early fifties, in private practice in London as a vaccine therapist. The fullest account of his views on therapeutics is contained in W M Crofton, The cure of acute and chronic infections by active immunisation, London, Bale, 1939.
}

\footnotetext{
${ }^{36}$ For an interesting account of aspects of the history of vaccine therapy, see $M$ Worboys, 'Vaccine therapy and laboratory medicine in Edwardian Britain', in J V Pickstone (ed.), Medical innovations in historical perspective, London, Macmillan, 1992, pp. 84-103.

${ }^{37}$ Hansard, 20 April 1955, 463-4.

${ }^{38}$ Letter, D McAlpine to R Cave, 23 April 1955, SA/MSS/B.5. Emphasis in original.

${ }^{39}$ Untitled draft, May 1955, SA/MSS/B.5.
} 


\section{Malcolm Nicolson and George W Lowis}

[A]s one for whose benefit the Society was founded, I beg leave to make some observations. You say, "that it is very difficult for this Society to undertake arrangements contrary to established medical and hospital practice". This involves a misconception so profound as to be almost inexplicable. The doctor with whom I have an appointment is a highly qualified man ... His merits are in no way diminished by the fact that he does not work within the National Health Service ... I have referred to your misconception ... as "almost inexplicable", but ... I do begin to understand it. The antithesis between inside and outside the state service stands in the mind of the Society for a different antithesis, namely between "orthodox" and "unorthodox" methods of treatment ... The latter antithesis, moreover, is not so much between orthodox and unorthodox treatment as between orthodox neglect and unorthodox treatment. The orthodox members of the profession ... hardly treat their patients at all. I am $\ldots$ in touch with one of the foremost hospitals in London and have never received any treatment from it. The unorthodox practitioners, on the other hand, although they may be proved wrong, are at least treating the disease, and it is from them that a cure will be established, if ever ... It appears that the Society has made a great mistake in allowing the dead hand of medical negative orthodoxy to fall upon it. ${ }^{40}$

Bennett was certainly correct in his delineation of the Society's concern to be, above all things, orthodox. He was also right that it was the unorthodox practitioner that many sufferers from MS, impatient with what was on offer in the mainstream hospitals, would look to for active treatment, indeed for hope. ${ }^{41}$

As its income, membership and status increased, the Society gradually began to consolidate its involvement in research. In 1957, the General Council resolved to fund a programme of research fellowships, all applications being handed over to its medical advisors for consideration. ${ }^{42}$ The Medical Panel set up what was effectively a sub-committee, the Medical Advisory Research Committee (MARC), to scrutinize research applications. ${ }^{43}$ It was one such application which occasioned the first major controversy that the leadership of the Society had to face.

Dr (later Sir) Ludwig Guttmann was Director of the National Spinal Injuries Centre at Stoke Mandeville. ${ }^{44} \mathrm{He}$ was also a member of the MARC. In 1958, he applied to the Society for funding to undertake a study of the problems involved in the clinical management of severe multiple sclerosis. Advanced MS patients sometimes suffer from flexor spasms which produce rigid contortions of the limbs and trunk. These can be painful. They are, moreover, distressing for carers and can make the prevention and treatment of bedsores more difficult. Urinary incontinence and/or retention can also be a complication of some advanced cases. Excretory function was an major problem, not only for patients and their carers but also for the health

\footnotetext{
${ }^{40}$ Letter, V Bennett to L Porter, 4 July 1955 , SA/MSS/A.12. Bennett, a schoolteacher, had spoken on the radio about his MS and was a regular contributor to $M S N e w s$ throughout the mid-fifties.

${ }^{41}$ In the sixties, Bennett became actively involved in the breakaway Multiple Sclerosis Treatments Investigation Group, for which see below.

${ }^{42}$ Annual report of the Multiple Sclerosis Society of Great Britain and Northern Ireland, 1957, p. 4.
}

\footnotetext{
${ }^{43}$ Annual report of the Multiple Sclerosis Society of Great Britain and Northern Ireland, 1956, p. 2.

${ }^{44}$ By the late fifties, Guttmannn's pioneering work at Stoke Mandeville had improved the management of paraplegic patients and established him as a national hero. He was knighted in 1966. For biographical details and appreciation, see the special number of Paraplegia, May 1979, 17, issued to commemorate his eightieth birthday.
} 


\section{The Early History of the Multiple Sclerosis Society}

services as a whole. Degree of control over bladder and bowel was the most important single factor in determining whether or not an MS patient should be admitted to institutional care. ${ }^{45}$ Guttmann proposed to investigate how the medical treatment and nursing management of spasm and of incontinence and retention of urine could be improved.

However, the members of the Medical Advisory Research Committee considered their brief to be the support of basic research aimed at increasing understanding of the aetiology of the disease and advancing the possibility of a cure. They did not regard projects which related to improving the clinical management of the disease as falling within these terms of reference. ${ }^{46}$ Alleviation programmes were, in McAlpine's opinion, "not really ... research" ${ }^{47}$ Guttmann's application was accordingly refused. He resigned from the Research Committee in high dudgeon:

I must confess that never in my whole career as neurologist and scientist have I encountered such an incredible and indeed humiliating experience ... and I do not think for a moment that the British public would agree with such [an] irresponsible policy on the part of the Multiple Sclerosis Society. ${ }^{48}$

Guttmann seems to have been particularly annoyed at the Committee's decision because he had been encouraged to apply for funding by several members of the MS Society, including Cave himself. ${ }^{49}$ Moreover his intuition as to the sensibilities of the interested public proved to be reliable. As the news that the Research Committee was refusing to fund this sort of work filtered out to the membership, an angry reaction quickly ensued. Many members of the Society were, of course, practically and emotionally involved in precisely the sort of problem Guttmann had sought to alleviate. Miss Faith Wood, a member of the Society's General Council and Matron of the Ray Park Nursing Home, which cared for many MS patients, wrote a very emotional letter to Cave, from which it is worthwhile quoting at length:

I [was] very dismayed ... to hear from Dr. Guttmann, that you had decided not to give him the research fellowship, and that this had been awarded to yet another bio-chemist, chasing up yet another nebulous round the corner cure. I feel so strongly about this that I am immediately writing to protest ... If this decision was taken by the Medical panel, in my opinion it is all wrong, as this should be an advisory body and at least some of the people who work with the patients, and who subscribe, and work like Hell to raise money for the Society, should be consulted.

Now, having three fellowships, all for bio-chemists, surely the time has come for something to be done for the sufferers, and with all due respect to the panel, this consists of very eminent

\footnotetext{
${ }^{45}$ See $\mathrm{H}$ Miller, C A Simpson, W K Yeates, 'Bladder dysfunction in multiple sclerosis', $\mathrm{Br}$. med. J., 1965, i: 1265-9. For an account of the stigma associated with urinary incontinence, see $S$ $\mathrm{K}$ Toombs, 'The body in multiple sclerosis: a patient's perspective', in D Leder (ed.) The body in medical thought and practice, Dordrecht, Kluwer, 1992, pp. 127-37;

${ }^{46}$ Undated later marginal annotation to file copy of letter, R Cave to L Guttmann, 22 May 1958, SA/MSS/B.13.
}

\author{
${ }^{47}$ Quoted in letter, L Porter to D McAlpine, \\ 17 July 1959, SA/MSS/B.1. \\ ${ }^{48}$ Letter, L Guttmann to L Porter, 1 July \\ 1959, SA/MSS/B.13. \\ ${ }^{49}$ Letter, R Cave to L Guttmann, 22 May \\ 1958, SA/MSS/B.13.
}




\section{Malcolm Nicolson and George W Lowis}

men, so far removed from the actual patients that they only know half of the problems. These men are the people who are responsible for the medical scandal that the treatment of M.S. has become, for, are they not the experts from the teaching hospitals, who are only too ready to say "No, there is nothing more that we can do for you." We know only too well that there is much that can be done, and in our very humble way are getting it done but only by ... constant nagging at specialists ... I really think that it is disgraceful if you let this opportunity go, and I know that there are many other people in the Society who agree with me. ${ }^{50}$

Miss Wood was right on her last point. She was not the only member who thought that the Society should ignore the recommendations of its Advisory Research Committee and fund Guttmann's work anyway. Major Guy Armstrong, an influential member of the General Council and the Executive Committee, argued strongly that the ultimate authority with regard to the disbursement of the Society's funds ought to lie with the General Council:

I am a little worried in case the impression may be gained that the Medical Panel have the power to decide these matters on behalf of the Society. I am sure you will agree that Council are the only body competent to reach a decision on such matters-guided, of course, by the recommendations of the Medical Panel and the Executive Committee ... I hope, therefore, that you will be able to confirm that unnecessary alarm has arisen and that the final decision will be reserved for the Council. ${ }^{51}$

The Council was divided and had to hold an extraordinary special meeting to discuss the matter further. Feelings were running high and serious consideration was being given to acting independently of the MARC. McAlpine wrote to Cave threatening the resignation of the entire membership of the Medical Panel if their decisions were countermanded..$^{52}$ Armed with McAlpine's letter and the threat of his own resignation, ${ }^{53}$ Cave was able to persuade the special meeting of the Council to endorse the recommendations of the Advisory Research Committee and Guttmann's application was not supported.

The widespread disquiet which the Guttmann affair brought to light prompted a working party, chaired by Major Armstrong, to inquire into the constitution and administration of the Society, particularly with regard to the support of medical research. His report was considered by the Council on 1 April $1959 .{ }^{54}$ As already noted above, the Society had originally been somewhat diffident in its attitude to funding research. However, in response to pressure from the local branches, many of whom were now mature organizations, active and successful in fund-raising, the working party recommended that the support of scientific work be accorded a higher priority. However, Armstrong's report endorsed the principle that all decisions as to how the Society's research budget was to be spent were to be made by the Medical Advisory Research Committee, which was to continue to be completely independent of the Society. The MARC was, thus, formally recognized as being "Advisory" in

\footnotetext{
${ }^{50}$ Letter, F Wood to R Cave, 11 Nov. 1958, SA/MSS/B.13.

${ }^{51}$ Letter, G Armstrong to R Cave, 12 Nov. 1958, SA/MSS/B.13.

${ }^{52}$ Letter, D McAlpine to R Cave, 23 April 1959, SA/MSS/B.13.
}

\footnotetext{
${ }^{53}$ Letter, E Gowers to R Cave, 27 April 1959, SA/MSS/B.13.

${ }^{54}$ Details of the report of the Armstrong Working Party are from SA/MSS/A.44.
} 


\section{The Early History of the Multiple Sclerosis Society}

name only. It was to remain self-constituting and self-perpetuating, appointing its own chairman and members, with no time limit fixed on how long they could serve. ${ }^{55}$ Research aimed at improving the management of advanced MS patients was indeed to be funded by the Society, but the money was to come from its patient welfare budget rather than its research budget. In deciding how the welfare budget should be spent, the Research Committee was to be consulted but its recommendations were not to be absolutely binding on the General Council. ${ }^{56}$

Securing agreement to these arrangements seems to have involved Cave and Captain Ludovic Porter, the Society's Secretary, in some delicate negotiations with McAlpine.$^{57}$ But, finally, by means of this compromise, the General Council managed to create some freedom of action for themselves in the disbursement of their funds. The Society began to develop a programme of support for research designed to improve the nursing management of MS. In the sixties, for example, it sponsored an international symposium on bladder dysfunction and promoted a competition to improve the design of female bladder incontinence devices. ${ }^{58}$ But the Guttmann affair had also established that the MARC would brook no contradiction of its authority on medical matters and the report of the working party had formally endorsed the principle of its autonomous status.

Despite these changes, a substantial portion of the membership of the Society continued to regard the Advisory Research Committee as too narrowly constituted, too powerful and too remote from the realities of MS as experienced by sufferers and their carers. Some of the Council were concerned at the complete dominance of the Research Committee by neurologists. McAlpine responded to such criticism by asserting that "the committee as constituted is entirely capable of assessing any research project that has a clinical bearing". ${ }^{59}$ Nevertheless, in 1964, one member of the General Council sought to put down a motion regretting that the Advisory Research Committee did not contain a single urologist. ${ }^{60}$ Porter briefed Cave as to how to respond to this implied criticism of the competence of their medical advisors:

It has always been the principle that these gentlemen are neurologists and scientists particularly interested in M.S. research, and I believe you would encounter considerable resistance were it to be suggested to them that they should include members from another branch of the medical profession in their number. Particularly is it the case that their meetings are often held as part of neurological conferences which others would not attend. ${ }^{61}$

The motion was not put before the General Council. Clearly nothing should be done, at least in public, that might incommode the medical profession. The Medical Panel and the Research Committee remained a closed-shop for neurologists. This

\footnotetext{
${ }^{55}$ Letter, H Miller to R Cave, 10 Dec. 1965, SA/MSS/B.20.

${ }^{56}$ Letter, L Porter to D McAlpine, 17 July 1959, SA/MSS/B.1

${ }^{57}$ Note, L Porter to R Cave, 'Lunch with McAlpine, 18th March' (no date given), SA/MSS/ B.13. See also SA/MSS/B.1.

${ }^{58}$ Anon, 'Bladder dysfunction in multiple sclerosis', Lancet, 1964, ii: 813; Annual report of
}

\author{
the Multiple Sclerosis Society of Great Britain and \\ Northern Ireland, 1967, p.1; see also SA/MSS/B.4. \\ ${ }^{59}$ Letter, D McAlpine to R Cave, 23 April \\ 1959, SA/MSS/B.13. \\ ${ }^{60}$ Letter, George [no surname] to R Cave, 12 \\ Oct. 1964, SA/MSS/B.4. \\ ${ }^{61}$ Letter, L Porter to R Cave, 16 Oct. 1964, \\ SA/MSS/B.4.
}




\section{Malcolm Nicolson and George W Lowis}

was all done in the name of propriety in the relation between a lay charity and its medical advisors. As Dr Henry Miller, Physician to the Royal Victoria Infirmary, Newcastle, and a member of the MARC, put it, "Informed from its inception by a lively appreciation of the suspicion which such Societies engender in the minds of many doctors - especially perhaps those of eminence and seniority-the Multiple Sclerosis Society has virtually leaned over backwards to maintain the most correct and ethical relation to the medical profession."62

Many of the controversies in which the Society was later to be embroiled followed a pattern similar to the Guttmann affair to the extent that they were characterized by lay disenchantment both with the way in which the MARC was administrating the research budget of the Society and with the extent to which the Society was incapable of action independent of the Committee. Time and again sections of the Society's constituency wished to promote some line of research which seemed to them to be promising, only for the MARC to refuse to do so. The Society's leadership was usually caught in the middle, unable to respond to the demands of the membership for fear of offending the professional sensitivities of its panels of experts or for fear of compromising its "ethical relation to the medical profession".

"Ethical", in this context, functioned as a codeword expressing the MS Society's determination to have nothing to do with unorthodox or fringe medicine. The Society's policy on "new, untried" methods of treatment was clear:." "[T]here is a constant stream of enquiries about these treatments and claims from our members and we consider it an important function of the Society to advise our members against them." ${ }^{\text {"4 }}$ Multiple sclerosis therapy has, of course, long been a domain of quackery and accusations of quackery. Many extravagant therapeutic claims have been made in this area and some of these, no doubt, have originated from unscrupulous individuals seeking to prey upon the frailty and anxiety of some MS sufferers. Therefore, in MS research and therapy simply being respectable means a great deal. ${ }^{65}$ The boundary between what is orthodox and what is not is a sensitive one. It is, accordingly, rigorously policed. The British MS Society, partly because of its social composition and partly because of its close connection with the speciality of neurology, seems to have been particularly defensive in this regard. It was unthinkable to its leadership that they should not be above any suspicion. As Cave wrote to McAlpine: "I am quite sure that what gives me the most cause for pride in connection with the M.S. Society is the happy relations which it enjoys with the medical profession." ${ }^{66}$ Furthermore, as we have seen, the Medical Panel exerted strong pressure upon the Society to keep it toeing the orthodox line.

\footnotetext{
${ }^{62} \mathrm{H}$ Miller, 'What voluntary effort has done to fill research gaps', Medical News, 26th April, 1963, unpaginated. Henry Miller, Professor of Neurology, University of Newcastle, was a major figure in British neurology throughout the sixties and was a dominant force within the MARC until he resigned upon becoming ViceChancellor at Newcastle in 1968. For biographical details, see his obituary in The Times, 27 August 1976.
}

\footnotetext{
${ }^{63}$ Letter, E R Bickerstaff to J Walford, 24 Sept. 1969, SA/MSS/A.12.

${ }^{64}$ Letter, A C Waine to E R Bickerstaff, 26 Sept. 1969, SA/MSS/A.12.

${ }^{65} \mathrm{M}$ Nicolson and $\mathrm{C}$ McLaughlin, 'Social constructionism and medical sociology: the case of the vascular theory of multiple sclerosis', Sociol. Health Illn., 1988, 10: 234-61.

${ }^{66}$ Letter, R Cave to D McAlpine, 3 Dec. 1964, SA/MSS/B.19.
} 


\section{The Early History of the Multiple Sclerosis Society}

Thus, Cave and Porter, the two leading figures within the Society at this time, rigorously defended a strictly constitutional relation between the Society and the medical profession in general and its Research Committee in particular. As we have seen, they refused to allow the General Council to express any explicit criticism of McAlpine and his colleagues. However, it is noteworthy that, in private, they were themselves often exasperated with the attitude of their medical advisors. As noted above, in the late fifties, it had been decided that the Society should disburse the research portion of its income in the form of support for research fellowships. This scheme proved popular with the local branches since a branch that was particularly successful in fund-raising could have an award earmarked as its own. A fellowship could, for instance, be named after a particularly generous local benefactor, as the Lyons Fellowship was in Leeds, for example. The Portsmouth branch had managed to involve their Town Council in the fund-raising effort for an award to be known as the Portsmouth Fellowship. ${ }^{67}$ This was regarded by the local branch as a major coup. ${ }^{68}$

However, in April 1959, in the interval between the Portsmouth money being offered and being allocated, the Research Committee decided that such a "piecemeal" approach to research was unsatisfactory. They recommended that the fellowship scheme be discontinued and a major centre or centres should be set up for "co-ordinated research". ${ }^{69}$ Faced with the possibility of having to disappoint the Portsmouth Branch and annoy the local members, Porter wrote, urgently and confidentially, to Cave:

This recommendation, made without any reference to any of the Officers or Committees of the Society, and therefore presumably without up-to-date knowledge of the Society's finances and capabilities, appears to abrogate without notice the Research Policy of the Society approved by the Advisory Research Committee at the end of $1957 .{ }^{70}$

Porter noted that the Research Committee had agreed to the setting-up of the fellowship scheme but had not, in his opinion, implemented it energetically. To Porter's considerable annoyance, no awards had been approved for some time, nor were applications from suitable candidates being actively solicited: "We cannot as a Society continue to sit on our arses until a total of ... years elapses since the Advisory Committee gave us the last Fellowship."71

Porter was, moreover, willing privately to endorse an opinion to which he had been, as we have seen, strongly hostile in public - namely that the Research Committee was too narrowly constituted:

I am afraid that I am coming round to the views rather impolitely expressed by some of our more dissident members. I consider that the Advisory Research Committee could well take a leaf from the American Research Review Panel, whose nine "eminent scientists" representing

\footnotetext{
${ }^{67}$ Anon, '.. to encourage scientific research ..., MS News, 1959, Christmas, 5-7.

${ }^{68}$ B Brookwood, 'The Portsmouth story', $M S$ News, 1960, Spring, 4-6.

${ }^{69}$ L Porter, 'Memorandum by the Secretary', undated, SA/MSS/B.18.
} 


\section{Malcolm Nicolson and George W Lowis}

"various scientific disciplines or fields" meet two or three times a year. I believe that a great deal of our present trouble and the irritation and frustration that is undoubtedly the prevailing mood of the Council (and of others) is entirely due to our medical advisors' inactivity. I don't think it is good enough, but I don't quite know how to change it. ${ }^{72}$

Porter disapproved of the fact that there were several eminent workers in the field of multiple sclerosis research whom McAlpine, apparently for personal reasons, would not allow to become members of the Committee. He thought that McAlpine should resign the chairmanship of the MARC to allow a more energetic style of leadership. He concluded:

What all this boils down to ... is that McA/Lumsden, much as I admire them, do not run this Society and should at least take notice of our views. We, not they, are responsible for our public relations, to our [Charities] Registration Authority, and to our members. And though the cause and cure of M.S. is of course one of our main objects, it must not be allowed to obscure the fact that we are judged by our reputation, and that medical advice must take account of the world in which we live, which at present it shows remarkably little signs of doing. $^{73}$

In Porter's view, McAlpine and his colleagues were displaying a lofty indifference to the welfare of the Society. But Porter knew that there was little he, as a layman, could do about it, other than exerting moral pressure upon McAlpine, which he and Cave attempted to do by acting in concert. Their strategy seems to have been a combination of entertaining McAlpine for luncheon in the Palace of Westminster or at the better class of London hotel, and sending him "polite" letters calculated to, as Porter put it, "bring him up short". ${ }^{74}$ Cave wrote to McAlpine acknowledging the "feeling of frustration which I am sorry to say is now widely evident in the Society ... both you and I must face the fact that in the proper co-ordination of the Society's general and medical policy we have, for the moment, failed."75

In the sixties, dissatisfaction within the ranks of the Multiple Sclerosis Society began to translate itself into active sustained dissent. At this time, considerable attention was being paid to a treatment for multiple sclerosis developed by the French physician, Dr P Le Gac. Le Gac held that the symptoms of MS resulted from vascular lesions within the central nervous system which were the sequelae of rickettsial infection. His therapeutic regimen was predicated upon "neutralisation of the virus, elimination of toxins, stimulation of the cardiovascular system and restoration of the general condition". In Le Gac's view these objects could be achieved by prolonged use of wide-spectrum antibiotics, combined with physiotherapy and warm seawater or seaweed baths. Le Gac had published in reputable medical journals and had presented his theories to the Pasteur Institute. ${ }^{76}$ His ideas were, however, regarded with great scepticism among orthodox medical circles in Britain.

\footnotetext{
72 Ibid.

${ }^{73}$ Ibid.

${ }^{74}$ Ibid.

${ }^{75}$ Letter, R Cave to D McAlpine, 2 June 1959, SA/MSS/B.18.
} 


\section{The Early History of the Multiple Sclerosis Society}

Accordingly, the British MS Society, on the advice of its Medical Panel, refused to endorse the Le Gac treatment. ${ }^{77}$

In 1964, a new, rival, MS charity was formed, the Multiple Sclerosis Treatments Investigation Group (MSTIG), the object of which was "to establish, authoritatively, the potentialities, or otherwise, of the therapy advocated by Le Gac". ${ }^{78} \mathrm{Mr}$ Robert Walker, a sufferer from MS and one of the founders of the MSTIG, defended the setting-up of the new group on the grounds that not enough was being done to find a cure for the disease. ${ }^{79}$ The Investigation Group established the Multiple Sclerosis Research Fund Ltd, with a target of $£ 200,000$ for the first two years fundraising. ${ }^{80}$ A publicity campaign was launched in local newspapers. Captain Porter was not pleased:

It is of course infuriating that they have now got themselves registered as a charity with a similar name. Experience has however shown me that no society which recommends quackery has ever continued to succeed, and that the majority of people who subscribe more than a few shillings at a time on research do so only on the evidence of an Annual Report and audited accounts. $^{81}$

When the Investigation Group sought to set up its own medical advisory panel, the MS Society wrote to likely candidates to discourage them from joining. ${ }^{82}$

When Walker's initiative was reported in the national press, Mr Philip Brooke, Honorary Secretary of the Hull and East Riding Branch of the MS Society-one of the most active local branches-came to the defence of the national body, denying that insufficient emphasis was being given to research. ${ }^{83}$ The membership generally followed Brooke's lead and stayed loyal to the national Society. But the controversy surrounding Le Gac's therapy and the Investigation Group was not immediately extinguished.

In 1965, Professor Henry Miller, now Chair of the MARC, reported to A C Waine, who had succeeded Porter as the Society's Secretary, on the matter of Le Gac. While acknowledging that there were "quite effective methods of treatment for a number of diseases which are purely empirical and which lack anything in the way of rational or scientific respectability", Miller, nevertheless, considered that the evidence in favour of the Le Gac therapy was "inadequate to justify a trial of this form of treatment in Great Britain" ${ }^{84}$ This official refusal to investigate the French claims merely intensified the controversy. The Investigation Group received considerable public support for their campaign against what appeared to some to be the unreasonable obduracy of the MS Society. For instance, Christopher Perry, a prospective parliamentary candidate, wrote to the Southern Evening Echo:

\footnotetext{
${ }^{77}$ A C Waine, 'Interested in research?', $M S$ News, 1965, Autumn, 19.

${ }^{78}$ Letter, A England to Community Council of Lancashire, 17 May 1965, SA/MSS/A.38.

${ }^{79}$ Letter, A C Waine to M Hawkins, 20 March 1969, SA/MSS/A. 37.

${ }^{80}$ 'Sclerosis campaign is challenged', Daily Telegraph, 1 Aug. 1964, cutting in SA/MSS/A.37.
}

\footnotetext{
${ }^{81}$ Letter, L Porter to H Miller, 28 July 1964, SA/MSS/A.37.

${ }^{82}$ Draft circular letter, untitled and undated, SA/MSS/A.37.

${ }^{83}$ Quoted in 'Sclerosis campaign is challenged', Daily Telegraph, 1 Aug. 1964.

${ }^{84}$ Report, H Miller to A C Waine, 12 March 1965, SA/MSS/B.15.
} 


\section{Malcolm Nicolson and George W Lowis}

A Manchester-based society [i.e. MSTIG] has for a long time existed to attract attention for an English test of these ideas but has met with stubborn and incomprehensible resistance from the Multiple Sclerosis Society ... I should welcome inquiries from all interested so that pressure in this area could be exerted on the medical profession nationally and on the other responsible authorities who at the moment are not allocating nearly enough resources and money to developing a cure for these scourges. ${ }^{85}$

Eventually, in February 1969, the Research Committee acquiesced to public demand by approving an investigation of Le Gac's claims. Professor Ephraim Field, Director of the Demyelinating Diseases Unit at Newcastle, undertook to organize a study of the presence of antibodies to rickettsia among MS patients. The Executive Committee hoped that the membership would welcome this initiative:

There is no doubt that this positive action by the Society will receive widespread approval by Branches and members, as there has always been pressure for such a trial to be mounted so that the claims made by the MS Treatments Investigation Group can be refuted or confirmed. The former is considered by Professor Field to be the likely outcome of the trial. ${ }^{86}$

The Investigation Group welcomed the initiative but was unimpressed by the choice of Professor Field. Their complaint was the now familiar one that too narrow a range of expertise was represented on the Advisory Research Committee, in particular, and within mainstream MS research in general. Arthur England, a spokesperson for the MSTIG, wrote to Waine:

Dr Le Gac has given a full and detailed explanation of pathological processes which contribute to this condition ... Professor Field is, I believe, a neurologist and, with all due respect, I suggest that the aetiology of this complaint is not within his field of work ... It must be recognised therefore that the neurologist is unlikely to produce any way of eliminating this condition as its cause does not originate in the neurological field and it is suggested that this disease is being directed to the wrong specialist for treatment and that is why no progress has been made, or is being made, in a method of eliminating the distress which is being caused by this complaint. ${ }^{87}$

Field's investigations into the presence of rickettsial antibodies in MS patients were indeed negative. ${ }^{88}$ It would also seem that the Investigation Group did not remain active for very long. ${ }^{89}$ Thus Porter was right in his prediction that the new charity would not succeed. However, the reasons he gave for this opinion, which have been quoted above, are very revealing. Not only were Walker's group tainted with what Porter regarded as quackery, he believed they could not attract the right sort of social and financial backing. What mattered to Porter was the approbation of a

\footnotetext{
${ }^{85} \mathrm{C}$ Perry, letter to the editor, Southern Evening Echo, 13 March 1969; cutting in SA/ MSS/B.15.

${ }^{86}$ A C Waine, 'Le Gac treatment', Memo to Executive committee, Agenda item no. 7, 5 Feb. 1969, SA/MSS/B.15.

${ }^{87}$ Letter, A England to A C Waine, 8 Dec. 1969, SA/MSS/B.15.

${ }^{88}$ E J Field, 'Research Report 1969', SA/MSS/ B.20. It is noteworthy, however, that, despite the
}

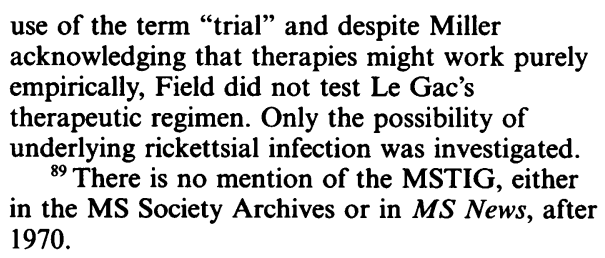
acknowledging that therapies might work purely empirically, Field did not test Le Gac's therapeutic regimen. Only the possibility of underlying rickettsial infection was investigated.

${ }^{89}$ There is no mention of the MSTIG, either in the MS Society Archives or in MS News, after 1970. 


\section{The Early History of the Multiple Sclerosis Society}

relatively small number of wealthy donors - the class of person who read the Annual Reports of the major charities before deciding where their tax-deductible lump-sum donations should go. In the sixties, the leadership of the MS Society remained wedded to a trickle-down conception of its charitable role. They were still not very interested in more democratic approaches to fund-raising or, one might surmise, to decision-making.

The other serious controversy in which the Society was involved in the sixties centred around the provision of research funding for Charles Lumsden, Professor of Pathology at the University of Leeds. Lumsden had been a senior member of the Medical Advisory Research Committee virtually since its inauguration. As we have seen, Lumsden's research into the immunochemistry of myelin had been supported by the MS Society since 1957, latterly through the Eleanor Brooke Memorial Fund, which had been set up by the Hull Branch, and which was subscribed to largely by the Yorkshire branches. In 1966, the MARC, in line with the Society's policy of getting new research "off the ground" by supporting it through its early years and then handing the project over to other bodies to maintain, asked Lumsden to give an undertaking that, on the next occasion when he required substantial financial support, he would first approach the Medical Research Council. ${ }^{90}$ Lumsden agreed to this request ${ }^{91}$ but, early in 1967, he applied again to the MS Society for research funds. The Research sub-committee referred the application to the next full meeting of the Research Committee, due to take place in April.

Lumsden had developed strong personal links with the Hull Branch, and Philip Brooke, its Honorary Secretary, knowing of the forthcoming application, wrote to Waine suggesting that the General Council should immediately lend Lumsden sufficient funds to keep his research going, with the Hull Branch committing itself to raise the money to repay the loan. ${ }^{92}$ Waine deprecated this proposal as an attempt to circumvent the "very necessary machinery" of the MARC. ${ }^{93}$ The General Council "resolved to await further consideration by the Medical Advisory Research Committee". ${ }^{44}$ These events produced a storm of protest from Yorkshire. The national Society was accused of displaying a deplorable lack of urgency in its support of important research. ${ }^{95}$ Efforts were again made to raise in the General Council the question of the Society's inability to act independently of its medical advisors.

At its April meeting, the MARC refused to provide any further funds for Lumsden. ${ }^{96}$ However, Cave and Waine had been very concerned at the strength of feeling expressed by the Yorkshire membership and had been able, by much behindthe-scenes negotiating, to wrest some concessions from the Committee. Waine wrote to Philip Brooke:

\footnotetext{
${ }^{90}$ Letter, A C Waine to C E Lumsden, 16 June 1966, SA/MSS/B.18.

${ }^{91}$ Letter, C E Lumsden to A C Waine, 12 Sept. 1966, SA/MSS/B.18.

${ }^{92}$ Letter, P Brooke to A C Waine, 30 Dec. 1966, SA/MSS/B.18.

${ }^{93}$ Letter, A C Waine to H Garland, 14 Feb. 1967, SA/MSS/B.18.
}

\footnotetext{
${ }^{94}$ Letter, A C Waine to P Brooke, 24 Feb. 1967, SA/MSS/B.18.

${ }^{95}$ Letter, P Brooke to A C Waine, 9 Feb. 1967, SA/MSS/B.18.

${ }^{96}$ Letter, A C Waine to C E Lumsden, 7 April 1967, SA/MSS/B. 18.
} 


\section{Malcolm Nicolson and George W Lowis}

The Committee gave special consideration to the point you made concerning urgency and the frequency of their meetings, particularly as this request came from the Yorkshire Branches. I am glad to be able to tell you that the Committee has agreed to meet three times a year instead of twice a year as at present. Furthermore, the Sub-Committee, which previously had no authority to recommend applications, is now authorised to do so in cases of an urgent nature within certain financial limits. The two decisions will considerably help in future cases where a decision is urgently required. ${ }^{97}$

Moreover, Dr Hugh Garland, now Chair of the MARC, agreed to attend a meeting of the Association of Yorkshire Branches "to explain personally ... the reasons for the Committee's decision concerning Professor Lumsden's application". 98

These were important concessions but the last measure by which Waine hoped to placate the Yorkshire members turned out to be a serious miscalculation. Garland was a physician at the Leeds Royal Infirmary, but he was seriously out of touch with the mood of the county on this issue. Moreover, as a senior consultant who tended to take for granted the respect and deference of his colleagues and his patients, and who was unaccustomed to having his authority questioned, he was very illequipped for the task of charming and persuading a public meeting of independently minded and resentful lay people. ${ }^{99}$

Garland's address to the Association of Yorkshire Branches completely disrupted the meeting and rendered any further constructive discussion impossible. Brooke described to Waine the feelings of his members:

To put a man on a public platform who could do no better than talk down to an obviously intelligent audience, to talk "old hat", much of which was decently buried years ago and to toss in a sneer for good measure ("high-falutin' research which neither you or I could understand") was a waste of time to people who had travelled many miles to listen to it. It was an insult. ${ }^{100}$

Lumsden had explained his work personally to Branch meetings in Yorkshire. He had arranged visits to his laboratory for local members and staged demonstrations of his investigations. Lumsden's lay visitors had certainly gained a very favourable impression indeed of his laboratory's contribution to the knowledge of their disease: "With this complete 'run-through' we could see that no logical step had been omitted and we realized ... that the cause of M.S. is no longer really a problem and the essential causes of the demyelination and sclerosis are understood."101 Doubtless many of Garland's audience felt that they did understand the nature of Lumsden's research, at least in outline.

\footnotetext{
${ }^{97}$ Letter, A C Waine to P Brooke, 7 April 1967, SA/MSS/B.18.

98 Ibid.

${ }^{99}$ Garland died suddenly in Oct. 1967 and it may well have been that the balance of his mind was already disturbed when he spoke to the Yorkshire Branches. However, the fact that their medical advisors generally tended to lack skills in the popular presentation of their policies was a persistent problem for the MS Society. In 1985, one of us (Nicolson) heard the then Chair of the MARC, Dr Reginald Kelly, seriously antagonize
}

a public meeting organized by the MS Society in Edinburgh, when feelings were running high over the MS Society's refusal to endorse hyperbaric oxygen therapy. He had evidently assumed a deference to his status, authority and expertise which many of his audience were quite unwilling to supply.

${ }^{100}$ Letter, P Brooke to A C Waine, 18 May 1967, SA/MSS/B.18.

${ }^{101}$ Unsigned undated account of visit to Lumsden's laboratory, probably prepared for publication in a Branch Newsletter, SA/MSS/B.18. 


\section{The Early History of the Multiple Sclerosis Society}

Lumsden presented his work as raising the possibility that eventually a means might be found to de-sensitize the immune response of MS patients in a way similar to the treatments which could be offered to asthma or hay fever sufferers. To an extent which, no doubt, Lumsden did not wholly intend, the optimistic rhetoric of the medical researcher fed and encouraged the impatience and urgency of the MS sufferer. There seems to have been a widespread belief in Yorkshire that a real breakthrough was imminent. Thus, the Yorkshire membership felt themselves to be campaigning not just for Lumsden and his work in immuno-chemistry but for a cure for multiple sclerosis. Hence the intensity of their reaction to the negative decision of the Research Advisory Committee.

Garland also seems seriously to have underestimated the degree to which his audience personally identified with the funds they had raised for the Society and with the Eleanor Brooke Memorial Fund in particular. John Towse, Chair of the Hull Branch, wrote to Cave to protest:

His irresponsible reference to the late Eleanor Brooke, in the presence of her husband, her sister [Mrs Irene Weaver, President, Hull Branch] and six of her friends, who hold her memory in the very highest esteem, as "some individual", was quite unforgivable and I had no option but to intervene and register my protest. It is a chastening thought that the research efforts of our Society are in the hands of a man who chooses to make such ill-mannered and illchosen remarks about members of a voluntary organisation who have given up much of their spare time and effort over a considerable number of years in the effort to discover the cause and cure of multiple sclerosis. ${ }^{102}$

Both Towse and Brooke conveyed to the leadership of the MS Society that they no longer had any confidence in Dr Garland or the Advisory Research Committee. Accordingly, they would no longer be bound by the Committee's recommendations. Towse told Cave:

I shall emphatically oppose, on every possible occasion, the diversion of any funds, from any source within my jurisdiction, to any Research Project that is controlled in any way by $\mathrm{Dr}$ Garland. The Hull and East Riding Branch will continue to support Prof. Lumsden, through the Eleanor Brooke Memorial Fund, even though we do so alone and become bankrupt in the process because we are very sure that a major breakthrough in research is imminent, largely as a result of Prof. Lumsden's inspired work. We shall also, to the best of our ability, provide him with whatever additional equipment he may need to speed his programme. ${ }^{103}$

Cave and Waine were faced with what was, in effect, a schism ${ }^{104}$-Waine, in a letter to Henry Miller, compared the situation to the Rhodesian unilateral declaration of independence. ${ }^{105}$ The Hull Branch, by refusing to channel the funds it collected for research though the national Society, was effectively declaring itself to be an independent multiple sclerosis charity. The Society had moreover lost, in Towse and especially in Brooke, the support of individuals who, as we have seen, had staunchly defended the national leadership in earlier difficulties.

\footnotetext{
${ }^{102}$ Letter, J Towse to R Cave, 17 May 1967, SA/MSS/B.18.

${ }^{103}$ Ibid.

${ }^{104}$ Letter, Bill [A C Waine] to Richard [Cave],

19 May 1967, SA/MSS/B.18.
}

\author{
${ }^{105}$ Letter, A C Waine to H Miller, 26 June \\ 1967, SA/MSS/B.18.
}




\section{Malcolm Nicolson and George W Lowis}

The Executive of the MS Society were also, uneasily in their case, of the opinion that Lumsden's work might represent genuine progress toward an understanding of the putative immunological basis of multiple sclerosis. They were embarrassed that the Society seemed to be lessening its support for potentially important work. As Waine agonized to Miller:

It would be a terrible thing for the Society if he stopped his work and then, one day the Americans, say, claimed an outstanding success on the same lines on which he had been (and had stopped) working. ${ }^{106}$

Nevertheless, Cave and Waine felt duty bound to go along with the decisions of their medical advisors. To them, there was, as we have seen, a matter of real principle at stake, upon which the integrity of the MS Society depended.

Professor Miller, on the other hand, seems to have regarded both Lumsden and his research with considerably less enthusiasm. ${ }^{107}$ Lumsden, he considered, had not been devoid of personal motives in the dispute. He had allowed the progress which had been made in his laboratory to be exaggerated, and had behaved unprofessionally by cultivating such close links with the Yorkshire MS branches and by encouraging premature hopes among sufferers. Moreover, the Research Committee seem to have resented the fact that, in 1962, some of the Portsmouth money had been allocated to Lumsden's group in a way that had made the Committee's authorization merely a formality. Miller had been anxious since that time to find a mechanism "to try and ensure that we really do control payment actually and not nominally". ${ }^{108}$ Again the Society's membership, its executive and its medical advisors were all operating according to divergent agendas.

The ambition of Towse and Brooke to carry the whole of Yorkshire with them in their breakaway from the national Society was not fulfilled. The Halifax branch, whose chairman, Dr P Holmes, was a general practitioner, remained loyal to the Metropolitan leadership and to the principle of research expenditure being controlled by the MARC. ${ }^{109}$ Eventually, the Hull Branch seems itself to have been persuaded to come back into line.

Perhaps, if Garland had been more diplomatic or if the national leadership had been more politically astute or the Research Committee more flexible or conciliatory, the Yorkshire controversy might have been defused earlier or might never have reached such a pitch of intensity. But the sort of problem which developed in Yorkshire in 1967 was a structural one, given the social context of multiple sclerosis research in Britain at this time. Controversy of this kind was bound to happen, sooner or later.

As we have seen, medical researchers routinely gave the interested laity confusing signals. On the one hand, they maintained that scientific research was progressive - the

106 Ibid.

${ }^{107}$ Letter, H Miller to A C Waine, 14 Nov. 1967, SA/MSS/B.18. While Lumsden's work did not wholly elucidate the pathogenesis of multiple sclerosis, it did provide useful experimental models of demyelination, see D McAlpine, C E Lumsden and E D Acheson, Multiple sclerosis: $a$ reappraisal, Edinburgh, Churchill Livingstone, 1972

${ }^{108}$ Letter, H Miller to L Porter, 19 Nov. 1962 , SA/MSS/B.22.

${ }^{109}$ Letter, R Cave to H Garland, 23 May 1967, SA/MSS/B.18. 


\section{The Early History of the Multiple Sclerosis Society}

message, sometimes explicit, from Miller as well as from Lumsden, was that "success may ... be just around the corner". ${ }^{110}$ On the other hand, MS sufferers were simultaneously being told to be patient, that much more basic research was required, that not every claim could be taken at its face value and that proper procedures had to be gone through. It was understandable that, uplifted by the first message, sufferers should sometimes regard the second as pettifoggery or obstructionism. As a contributor to an MS newsletter put it:

MS sufferers and their families feel very impatient indeed about research, and ... any apparent dragging of feet ... must often bring on feelings of near-panic and frustration. As one lady very movingly said: "We just haven't got the time."

This is where leadership and diplomacy by the officers of the Society might have played, and indeed often did play, a central role in balancing aspirations, creating compromises and diverting energies along non-disputatious pathways. However, as we have seen, the leadership of the MS Society operated, to a significant extent, according to a different agenda from the membership as a whole-they felt themselves to be acting on behalf of the sufferer members of the Society, but many MS patients, in common with other groups of the disabled or chronic sick, increasingly wished to organize themselves rather than depend on the well-meaning able-bodied to act for them. ${ }^{112}$ Moreover the leadership's freedom of action was often crucially curtailed by the extent to which they had devolved executive authority to the Advisory Research Committee. The principle that the MARC should be independent, selfconstituting, and sovereign on matters relating to research inevitably created social distance between it and the membership of the Society whose funds it was disbursing - a distance which the leadership could often do little to close.

This is not to say that the ordinary membership could never turn the tables and impose its will upon the Research Committee. As we have seen above, if public pressure was sufficient, as in the Le Gac case, the Committee might feel it politically incumbent upon them not to appear wholly insensitive to the wishes of the interested laity. But they tended to make such moves reluctantly and with little enthusiasm. Unfortunately for the leadership of the Society, the manner of the MARC's concessions to public opinion often heightened rather than diminished the membership's feelings of frustration and impatience with the attitude of their medical advisors.

A fairly typical example of the behaviour of the MARC while under pressure from the lay membership is provided by the controversy surrounding the Hawthorn diet. Reginald Hawthorn, a physiotherapist who ran a health farm in Suffolk, had developed a dietary treatment for multiple sclerosis, based on the avoidance of all refined foods, carbohydrates and alcohol. Hawthorn's recommendations were broadly

\footnotetext{
${ }^{110}$ H Miller, 'Science Survey-Multiple Sclerosis', transcript of radio broadcast, undated, SA/MSS/B.22

${ }^{111}$ Anon., 'Lively meeting in Bloomsbury', Outlook [Newsletter, South-West London Branch], undated, unpaginated. SA/MSS/A.4.

${ }^{112}$ For the history of the key change from "organizations for" to "organizations of" the
}

\author{
disabled, see J Campbell and M Oliver (eds), \\ Disability politics: understanding our past, \\ changing our future, London, Routledge, 1996; \\ and L Barton and M Oliver (eds), Disability \\ studies: past, present and future, Leeds, Disability \\ Press, 1997.
}




\section{Malcolm Nicolson and George W Lowis}

similar to several other proposed therapies, such as those developed by $\mathrm{R}$ Shatin in Australia and by $\mathbf{J}$ Evers in West Germany. But, in the early seventies, considerable interest was generated in the Hawthorn diet because of the publicity surrounding the spectacular return to active employment of his most famous patient, the playwright, Roger MacDougall. ${ }^{113}$ MacDougall became an energetic publicist for Hawthorn's dietary treatment and, moreover, marketed vitamin dietary supplements for MS sufferers under his own name.

Again the MS Society was bombarded with letters seeking information about the new treatment. Local branches urgently requested that the Society immediately fund an investigation of the claims advanced by Hawthorn and MacDougall. Individual neurologists were confronted by large numbers of patients demanding to be put on the Hawthorn diet. In August 1975, Lord Willis, himself a playwright, wrote to the MS Society, querying whether MacDougall's ideas were being taken sufficiently seriously, and offering (or perhaps threatening) to raise the matter in the House of Lords. In fact, such was the public response to the newspaper articles about MacDougall that both the speciality of neurology and the MS Society seem, on this occasion, to have moved quite swiftly. Dr Reginald Kelly, now Chair of the MARC, replied to Lord Willis:

[A]s a result of the publicity that Robin [sic] MacDougall has managed to acquire with regard to his ideas, very large numbers of patients have demanded to be put on this diet and at the present moment pilot trials of the diet are being carried out, both in Edinburgh and Manchester, but not on a scientific basis, and these pilot trials have not suggested that it would be worthwhile to carry out a scientifically controlled double blind trial. However, because of the enormous clamour, the Multiple Sclerosis Society has supported a double blind trial which I am carrying out ... to see whether we can acquire any scientific evidence as to the value or otherwise of the theories that are advanced by Robin [sic] MacDougall. I shall have to acquire at least 100 patients and to follow them up for a number of years. This is a very considerable labour but we feel it is imposed upon us, although the pilot trials have not been at all encouraging, so as to satisfy the clamour of patients. ${ }^{114}$

Thus, whereas the membership's attitude to the Hawthorn diet expressed eager enthusiasm and renewed hopefulness, the Research Committee responded with scepticism and only grudging compliance. To the neurologist, what seemed appropriate in the field of MS research was the conservative allocation of scarce investigatory resources. To the MS sufferer, anything new was worth following up and as soon as possible. Cautious, professional equivocation could sometimes be reacted to with bewilderment, frustration and anger. There were, moreover, those who wondered if a fair assessment of unorthodox treatments was possible under the auspices of a body of men who seemed routinely to pre-judge the issue of their effectiveness.

These simmering tensions came to the boil during the Field affair of the midseventies. Professor Ephraim Field, as we have seen, was the Director of the Demyelinating Diseases Unit in Newcastle and had been the spokesman for the

\footnotetext{
${ }^{113}$ K Hurren, 'A dramatic revival', Daily Telegraph Magazine, 11 Aug. 1974, 32-8.
}

\footnotetext{
${ }^{114}$ Letter, R Kelly to Lord Willis, 7 Aug. 1975, SA/MSS/B.7.
} 


\section{The Early History of the Multiple Sclerosis Society}

Society during the Le Gac affair. His Unit was one of the MS Society's success stories since it had been set up by the Society and then taken over by the Medical Research Council. ${ }^{115}$ Field claimed to have developed a diagnostic blood test for MS. He suggested, moreover, that his test would enable the early identification of children who were susceptible to MS in later life. ${ }^{116}$ Linking this work to other British research on the effectiveness of sunflower oil diets in the treatment of $\mathrm{MS},{ }^{117}$ he proposed that, if sunflower oil or some other dietary supplement could indeed mitigate the development of the disease, children identified as being at risk might be put on a preventative regimen from an early age. This possibility was greeted with enthusiasm by many MS sufferers who took comfort in the possibility that at least their children might be spared the ravages of the disease.

By 1973, Field's diagnostic blood test had not been independently corroborated. It was not, however, the scientific status of his claims which suddenly made him an object of national controversy. The Demyelinating Disease Unit was acknowledged to be one of the major centres in the world for research into multiple sclerosis. Field's difficulties centred around questions of personality and man-management skills. The MRC had been concerned for some time about rumours of problems in Newcastle. In May 1972, one of their personnel officers visited the Unit, interviewed staff and reported back that there was a case to answer. But no immediate action was taken. Tired of waiting for some intervention by the MRC, one of Field's colleagues took the matter to the Association of University Teachers. A formal complaints procedure was instigated. In October 1972, the MRC again investigated Field's relationships with his staff and, in May 1973, he was dismissed from the Directorship. The MRC offered Field a reduced team of five assistants to continue his work in other premises but he refused this facility as being inadequate for his research, which he claimed was dependent upon all the support services provided by the Unit, especially its animal house. Meanwhile the scientific work of the Demyelinating Diseases Unit effectively ground to a halt. ${ }^{118}$

Field's dismissal quickly attracted widespread attention. A group of MPs including Alfred Morris, an Opposition Health spokesman, tabled an Early Day Motion in the House of Commons calling for a full inquiry and claiming that "public money had been wasted" and "research into this most distressing disease of multiple sclerosis has been severely hindered". ${ }^{119}$ Margaret Thatcher, the responsible minister, responded by saying that it would be improper for the Government to interfere in the affairs of the Research Council. Articles appeared in the national press, most of which were broadly sympathetic to Field and critical of the MRC, who were accused of having

\footnotetext{
${ }^{115}$ Letter, R Cave to Sir J L Gray, undated, SA/MSS/B.11; Anon,'An important research appointment', MS News, 1958, Summer, 5.

${ }^{116} \mathrm{E}$ Field, et al., 'Specific laboratory test for diagnosis of multiple sclerosis', Br. med. J., 1974, i: $412-14$.

${ }^{117} \mathrm{~J}$ H Millar, et al., 'Double-blind trial of linoleate supplementation of the diet in multiple sclerosis', Br. med. J., 1973, i: 765-8.
}

\footnotetext{
${ }^{118}$ The information in this paragraph is mostly taken from an unsigned and undated MRC memorandum 'Demylinating Diseases Unit' in SA/MSS/B.11.

119 'Research into multiple sclerosis in Newcastle upon Tyne', Notice of Questions and Motions, House of Commons, no. 26, 4 Dec. 1973, 1462.
} 


\section{Malcolm Nicolson and George W Lowis}

acted tardily and in a heavy-handed manner. ${ }^{120}$ The MRC, indeed, was criticized for displaying a lack of precisely those man-management skills it had accused Field of not possessing. The Sunday Times spoke of "potentially tragic delays in research". ${ }^{121}$ Field, meanwhile, was represented in the media as a brilliant and caring, if somewhat obsessional and irascible, medical researcher whose principal failing was that he had been surrounded in Newcastle by colleagues less dedicated than himself. In terms which embodied popular images of the scientist at work, he was portrayed as an eccentric, driven genius, who did not suffer fools gladly.

Among the membership of the MS Society, initial sympathies were certainly with Field. He was invited to speak to several branches and George Smith, founder of the Peterborough Branch, reported:

[Field] addressed an audience of over 250 people who were held spellbound by his masterful appraisal and sincere message of hope for the future ... "The Prof" was a tremendously dedicated worker for research and one whom the movement and people so terribly handicapped by Multiple Sclerosis can ill afford to lose. My respect for him is unbounded and I sincerely hope that you will be able to help in this very difficult situation. ${ }^{122}$

Field indeed actively canvassed the Society's members for their support. He sent a letter to the branch secretaries asking them to write to their MPs on his behalf. However, neither Waine nor Cave wanted the Society to become involved in what had already developed into a political dispute, "because of possible harm to the Society's charitable status". ${ }^{123}$ Waine circulated this cautionary advice to all the branches, arguing, moreover, that it "would be quite wrong to involve our patient members in a controversy of this nature. It would cause them unnecessary worry to do so." 124 This protective paternalism constituted a serious misreading of the sentiments of the membership, a sizeable proportion of whom seem, on the contrary, to have been worried that their Society was not playing a sufficiently active role in the affair. There was talk of the setting up of a splinter organization of MS sufferers:

... a ginger group prepared to cut corners, make a fuss-and possibly a few enemies as well ... consumed Shelter-style with the urgency, indignity and injustice of their position as cripples in a world where the healthy call the shots and prepared, Prof. Field-style, to spare themselves no sacrifice to improve the situation. ${ }^{125}$

Cave wrote to Sir John Gray, the Secretary of the MRC, and meetings were organized between the Society and the Research Council, together with other interested bodies, to discuss the overall direction of MS research in the UK, and Field's place within it. ${ }^{126}$ As a result of these meetings, both the MS Society and the MRC stated publicly that they would welcome applications from Field for funding for specific projects.

\footnotetext{
${ }^{120} \mathrm{R}$ Lacey, 'The politics of multiple sclerosis', Sunday Times, 28 April 1974.

${ }^{121}$ R Lacey, 'Multiple sclerosis: some new hope', Sunday Times, 12 May 1974.

${ }_{122}$ Letter, G Smith to R Cave, 1 Feb. 1974, SA/MSS/B.11.

${ }^{123}$ R Cave, 'Professor Field-An announcement on behalf of the Multiple Sclerosis
}

Society of Great Britain and Northern Ireland', Sunday Times, 2 June 1974.

${ }^{124}$ Letter, A C Waine to All Branch

Secretaries, 14 Dec. 1973, SA/MSS/B.11.

${ }^{125} \mathrm{R}$ Lacey, 'The politics of multiple sclerosis', Sunday Times, 28 April 1974.

${ }^{126}$ Letter, R Cave to Sir J L Gray, 13 Dec. 1973, SA/MSS/B.11. 


\section{The Early History of the Multiple Sclerosis Society}

Cave wrote to the Sunday Times explaining the Society's position and expressing the "hope that Professor Field will be able to come back into the fold and continue his work. We desperately need men of his dedication and calibre." 127 But Cave refused to lobby the Government directly on Field's behalf, repeating Waine's warning that this might endanger the Society's charitable status: "the Society could no more engage in such activities than it could conduct its own medical research." ${ }^{128}$

For some, all this was too little, too late. On 22 May 1974, an anonymous telephone caller informed J T Walford, Deputy Secretary of the MS Society, that a meeting of disaffected members of the Society had taken place two days earlier and that a resolution to form a ginger group had been passed unanimously. The Multiple Sclerosis Action Group (MSAG) was formally inaugurated on 14 June 1974. John Simkins, formerly Chair of the Newham Branch and now Chair of the MSAG, wrote to Cave officially informing him of the setting-up of the new organization and indicating that the "new Group has the strongest desire to work with, and as far as possible, within the Multiple Sclerosis Society". ${ }^{29}$ The aims of the Action Group were to enable promising research ideas to be followed up more swiftly than had previously been possible, to promote research in a manner which more closely reflected the wishes of the membership, to fund work on the sunflower oil diet, and to support Professor Field with every means at its disposal. ${ }^{130}$ Criticism of the Executive of the MS Society was explicit:

The recent events concerning the research work of Professor Field have highlighted the apparent inability of the M.S. Society ... to be effective in resolving such difficulties ... It is not the Field affair in itself that has aroused so much intelligent concern, but rather the now easily identifiable knowledge gaps and ... attendant uncertainty, about the M.S. Society's influence upon, and/or management control of, all M.S. research projects in the U.K. ${ }^{131}$

The Field affair had not been the only reason for the creation of the new group, but it had been the "trigger which finally convinced people of the need for more direct action". ${ }^{132}$

A meeting took place between the Action Group and members of the General Council of the MS Society on 17 July 1974, but no agreement was reached. ${ }^{133}$ The immediate reaction of the hierarchy of the Society to the founding of the new group was hostile. An editorial in $M S$ News defended the record of the Society, argued that "any other efforts can only be divisive rather than constructive", and noted that the "Multiple Sclerosis Society has decided at top level that it will not be associated in any way with this new group". ${ }^{134}$ Some members thought, however, that the Society should not be complacent. B S Farley, Assistant Secretary of the

\footnotetext{
${ }^{127}$ Letter to Editor, R Cave, Sunday Times, 2 June, 1974.

${ }_{128}$ Ibid.

${ }^{129}$ Letter, J Simkins to R Cave, 14 June 1974, SA/MSS/A.36.

${ }^{130}$ From anonymous, unsigned Action Group leaflet in SA/MSS/A.36.

${ }^{131}$ Letter, J Simkins to R Cave, 14 June 1974, SA/MSS/A.36.
}

\footnotetext{
${ }^{132}$ Letter, J Simkins to A C Waine, 5 July 1974, SA/MSS/A.36.

${ }^{133}$ 'Multiple Sclerosis Action Group. Notes on a meeting between this Group and representatives of the Council of the Multiple Sclerosis Society ... 25th February, 1976'. SA/MSS/A.36

${ }^{134}$ A C Waine, 'Editorial', MS News, 1974, 1; Letter, R Cave to J Simkins, 10 Aug. 1974, SA MSS/A.36.
} 


\section{Malcolm Nicolson and George $W$ Lowis}

Harlow, Bishop's Stortford and District Branch, wrote to Waine, pledging his loyalty but expressing the hope that the Action Group would be allowed to "work in close co-operation ... with the MS Society". He continued:

I am sure that a dynamic Action Group will appeal to younger and dynamic M.S. members ... If a gulf develops, I feel the M.S. Society will suffer as the more energetic people will probably migrate to the Action Group. Please excuse me for saying so, but the M.S. Society has a rather staid image in my eyes and tends to regard M.S. sufferers as hospitals regard patients-i.e. they need protecting. This needs changing. ${ }^{135}$

On Waine's behalf, Walford dutifully replied:

... perhaps you are mistaking the Society's responsible outlook for what you describe as "a staid image". There is an immense difference and in the view of the Society it is of paramount importance to retain this attitude of responsibility. ${ }^{136}$

Waine organized press releases giving details of the MS Society's activities and questioning the need for a separate organization. Throughout the dispute, Waine particularly and regularly deplored the Action Group's "allocation of funds for research without medical or scientific advice". ${ }^{137}$ This procedure, he maintained, put the Action Group beyond the pale as far as the Society was concerned. The Secretary of the Action Group, however, regarded this as a misrepresentation:

As to the question of medical advisors, we take detailed and considerable counsel and we do not share the Society's views that administrative and executive decisions should rest with a Medical Committee but leave the doctors to follow their disciplines and we follow ours ... It does seem to me that the Council works with very little regard to the general membership and its wishes. ${ }^{138}$

The Action Group would soon have its own panel of medical advisors but it appointed them directly, for a fixed term, and did not consider their recommendations to be absolutely binding on the executive.

The 1974 Annual General Meeting of the MS Society passed two significant resolutions. ${ }^{139}$ One required the setting-up of a Working Party to enquire into the organization and operation of the Society, and the other, proposed by the Loughborough Branch, demanded that the General Council do all in its power to get Field back to work. Simkins wrote to all members of the General Council offering to co-operate with the Society on these matters:

[O]ne ... of the aims of the Action Group is to make it possible for Professor Field to either prove or disprove his theories. Because of official lethargy, and in some quarters antipathy, to this project, we feel that with our very direct style of approach, we may be able to offer a

\footnotetext{
${ }^{135}$ Letter, B S Farley to A C Waine, 20 Aug. 1974, SA/MSS/A.36.

${ }^{136}$ Letter, J T Walford to B S Farley, 21 Aug. 1974, SA/MSS/A.36.

${ }^{137}$ Letter, A C Waine to W Johnston, 3 Dec. 1975, SA/MSS/A.36.
}

\footnotetext{
${ }^{138}$ Letter, J Potter to A C Waine, 13 Dec. 1974, SA/MSS/A.36.

${ }^{139}$ Anon, 'Minutes of the 20th Annual General Meeting', MS News, 1974, Christmas, 9-13.
} 


\section{The Early History of the Multiple Sclerosis Society}

great deal of help to you as a Council in making the necessary arrangements to translate the resolutions intó action. ${ }^{140}$

Simkin's offer of assistance was declined. But a Working Party was convened, under Sir Ranulph Bacon, to report the following year. ${ }^{141}$

The 1975 Annual General Meeting was one of the most bitterly divided that the Society had ever seen. As a Camden member described it: "The real world hit me on 3rd October when I trundled along to the National Society's AGM . . . Boy, was I dropped into a world of dissatisfaction I did not understand!"'142 The Loughborough branch, many of whose members were also supporters of the Action Group, moved a motion condemning the General Council for not acting upon previous resolutions to support Field and urging that he should immediately be granted $£ 10,000$ for altering a laboratory and $£ 40,000$ a year for three years research. ${ }^{143}$ (These were enormous sums in the context of a Society whose annual research budget at this time was approximately $£ 100,000$ ):

There then followed a fascinating scientific dialogue between Prof. Field and Prof. Davison [a member of the MARC] which was nipped in the bud by the Chairman [Cave] who said that we couldn't debate medical matters in front of a lay audience. Someone asked why not? and was stamped on in such a way by the hierarchy that I stopped abstaining and voted against the platform from then on. ${ }^{144}$

The meeting broke up in confusion and acrimony.

Lt-Colonel Francis Kerr, a member of the General Council, wrote to Cave the following week:

I must write a line to you about the AGM ... which I thought was the most unpleasant meeting I have ever attended. I feel that I did not give you the support you deserved from the floor but the Action Group were not open to reason and anything I said only seemed to make them worse. ${ }^{145}$

Colonel Kerr felt that the attitude of the leadership of the Society to the Action Group ought to be one of Christian charity and understanding:

I do feel, however, that the majority of the people who made the trouble were sick both mentally and physically and as anyone without faith is bound to be desperate about the future when they contract MS, one must make great allowances for them. ${ }^{146}$

Kerr's attitude may be contrasted with the view of the Action Group that "only sufferers from the disease could be genuinely or truly motivated to work in the service of sufferers, and could understand the feelings of other sufferers." ${ }^{147}$ Initially

\footnotetext{
${ }^{140}$ Letter, J Simkins to All Members of the Council, 13 Nov. 1974, SA/MSS/A.36.

${ }^{141}$ Bacon was a Director of Securicor Ltd., which had long had charitable links with the MS Society (see SA/MSS/A.50). He had previously been an Assistant Commissioner, Metropolitan Police; Who's Who, 1975, London, Black, p. 126.

${ }^{142}$ Anon., 'Angry grumbling mutterings', Photo-copied extract from Camden Branch Newsletter, 1975, SA/MSS/A.4.
}

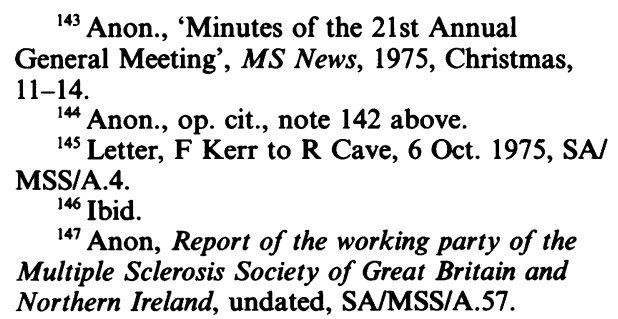




\section{Malcolm Nicolson and George W Lowis}

membership of the MSAG was confined to sufferers from MS and their immediate carers. It was very much conceived of as an "organization of", rather than an "organization for", the disabled and chronically ill, a collective within which MS sufferers could determine their own agenda of mutual support and socio-political action, rather than passively submit to what some regarded as the condescension of care by the able-bodied. ${ }^{148}$

Cave received several other letters of support following the AGM. Mrs Megan Faro and Brigadier Gordon Wade, respectively the Chair and President of the Harlow, Bishop Stortford and District Branch, wrote to express their sympathy and support:

We were sad that you were treated with great discourtesy by a small, ill-mannered but vocal minority whose continual attempts to disrupt the proceedings were detrimental to the best interests of our Society and discreditable to those concerned. So we want to tell you that their efforts in no way lessened the sincere admiration which we both have for the leadership and inspiration that you give to the great majority of members of the Society. From comments we heard after the meeting we are certain that you have the loyal support and affectionate regards of almost everyone who was present. ${ }^{149}$

Cave replied:

The sentiments which you express so elegantly have done much to take away the sour taste left by the distasteful Annual Meeting ... It is very disturbing that what you rightly call "a small, ill-mannered but vocal minority" should be able to upset the harmonious working of our Society. Over the long years we have all been one large happy family, and indeed we still are. I suppose that what happened at the Annual Meeting is a reflection of the world around us, and perhaps we are fortunate in having continued for so long without these ill-informed noises. ${ }^{150}$

The hierarchy of the Society was evidently having difficulty in adjusting to the fact that the Society was no longer a patriarchy and that a significant proportion of the membership was no longer prepared to be deferential and respectful. They saw this as a regrettable circumstance, but not something that they were directly responsible for. It was explicable in terms of social deviance or of pathology, either medical or theological. The leadership were not, in other words, prepared to negotiate with the Action Group on a basis of equality. The Society's executive exercised their constitutional right to refuse to allow certain members of the Action Group to be interviewed for seats on the General Council. ${ }^{151}$

These exchanges also indicate, moreover, that opinion among Cave's circle had hardened against Professor Field:

\footnotetext{
${ }^{148}$ See note 112 above. The Report of the working party contains many telling exemplifications of the divergence in the points of view of the two parties. The Action Group, for example, wished the MS Society to adopt a policy of preferentially recruiting MS sufferers to paid posts in its Head Office; the Society wished merely to ensure that there was no discrimination against sufferers in its employment practices.
}

\author{
${ }^{149}$ Letter, M Faro and C G C Wade to R \\ Cave, 10 Oct. 1975, SA/MSS/A.4. \\ ${ }^{150}$ Letter, R Cave to M Faro and C G C \\ Wade, 15 Oct. 1975, SA/MSS/A.4. \\ ${ }^{151}$ Letter, J Potter to A C Waine, 13 \\ December, 1974. SA/MSS/A.36
}




\section{The Early History of the Multiple Sclerosis Society}

Professor Field is a dreadful man, to my mind, the issue he was fighting [for] was not for MS research but for the advancement of his own career, and for this he was prepared to exploit the fear of MS sufferers. ${ }^{152}$

Cave replied:

The less said about Professor Field, the better, except that I am told that he has now forfeited the support of quite a number of our members, who up to last Friday were on his side. Thank you again for your letter-do you think that perhaps all this will help us along the road to Heaven? ${ }^{153}$

Later in 1975, Simkins wrote again to Cave offering to "help the Society and, of course, the MS cause generally through joint action". ${ }^{154}$ Cave agreed to attend a meeting of the Action Group but, much to their disappointment, went with a strict brief only to listen and not to engage in any discussion. Simkins had "hoped for agreement on at least one area of co-operation". ${ }^{155}$ But the leadership was determined to stick to its decision to have nothing to do with the Action Group, and to refuse to allow it to affiliate to the Society.

The Special General Meeting on the Report of the Working Party took place in the Great Hall of the University of Nottingham, in March 1976. The leadership of the MS Society prepared very carefully for this showdown with the Action Group. It is an indication of Cave's considerable clout among the great and the good that he was able to arrange for the Special Meeting to be presided over by Lord Dilhorne, a former Lord Chancellor. ${ }^{156}$ Cave saw to it that the learned judge was well briefed for his task. Furthermore, loyal members of the Society were detailed to stand at the ends of rows occupied by supporters of the Action Group so as to identify potentially disruptive elements to the chair. ${ }^{157}$ Cave also engaged the Bishop of Leicester to lead the assembly in prayer before the meeting proper started:

Unfortunately, during the past two years, a number of militant members of the Society have become tiresomely vocal. It is Lord Dilhorne's hope and mine that you may perhaps be able to instil into them a few of the gifts of the Holy Ghost, at any rate for the afternoon. ${ }^{158}$

The introduction of the Bishop was a deliberate attempt by Cave to create an atmosphere of conciliation and deference to authority. He afterwards wrote to thank the Bishop and to say that he had especially appreciated his plea for the company to lay "aside all private interests, prejudices and partial affections". 159

\footnotetext{
${ }^{152}$ Letter, F Kerr to R Cave, 6 Oct. 1975, SA MSS/A.4.

${ }^{153}$ Letter, R Cave to F Kerr, 8 Oct. 1975, SA MSS/A.4.

${ }^{154}$ Letter, J Simkins to R Cave, 29 Nov. 1975, SA/MSS/A.36.

${ }^{155}$ Letter, J Simkins to R Cave, 8 March 1976, SA/MSS/A.36.

${ }^{156}$ R F V Heuston, 'Manningham-Buller, Reginald Edward, fourth baronet and first Viscount Dilhorne', Dictionary of national biography, Oxford University Press, 1986.
}

\footnotetext{
${ }^{157}$ It is an indication, however, of where the Society's priorities lay with respect to the organization of this meeting that it was only latterly realized that wheelchair access to toilets was not possible from the Hall. A corner was duly curtained off and buckets were provided; an arrangement not ideal for those with impaired balance. Anon. pers. com.

${ }^{158}$ Letter, $\mathbf{R}$ Cave to the Bishop of Leicester, 11 March 1976, SA/MSS/A.57.

${ }^{159}$ Letter, R Cave to the Bishop of Leicester, 29 March 1976, SA/MSS/A.57.
} 


\section{Malcolm Nicolson and George $W$ Lowis}

Not every one shared Cave's view on the value of the episcopal intervention, however. Some of the members protested at what they saw as a waste of time. Others "objected strongly to the assumption that no-one would mind prayers. I thought we were supposed to be non-denominational." 160 Eventually, however, the meeting got under way and the authors of the Working Party Report spoke to elucidate and defend their various recommendations. The gap between the perspectives of the hierarchy and the membership was soon apparent. One member described the events:

[P]eople from the Working Party came forward to justify bits of the Report that had been questioned. The first bloke dealt with the staffing recommendations ... and then in the inimitable manner which so endears the National Society to us all said they'd decided to stay in London for reasons he wouldn't go into!!! Yells of "Why not?" forced him to say that London is the central part of the country ... and everyone goes there. Chap next to me then grunted in a broad Yorkshire [accent], "Not if I can help it, I don't." The Secretary thought it important to be near government. I don't think he convinced the objectors. ${ }^{161}$

Nevertheless, despite much vigorous debate, the meeting accepted the recommendations of the Working Party more or less as they stood. The Report proposed that the General Council should be elected by the membership and this was enthusiastically endorsed. The meeting did however overwhelmingly reject the Working Party's proposal that prospective candidates for the General Council should still have to be approved by the Council before they could stand for election. On the other hand a Loughborough motion that the Council should be able to award research grants independently of the Advisory Research Committee was "howled down" without a vote. ${ }^{162}$ The meeting closed, however, with a vigorous speech from the floor, deprecating the Working Party's criticism of the counselling work undertaken by the Action Group. This drew enthusiastic applause and thus detracted considerably from the moral authority of this aspect of the Report.

Overall, the leadership seems to have been quite pleased with the outcome of the Nottingham meeting. Professor J J Pritchard, a member of the Research Committee, wrote to Cave to say: "I thought it was well worth while, and I am full of admiration for the way Lord Dilhorne chaired the meeting, and put the more vociferous members of the Action Group in[to] their 'boxes'."163 As far as the MS Society was concerned, the Special Meeting was certainly a success. The boat had been steadied and some popular and sensible reforms had been instituted. The leadership had been made somewhat more accountable to the membership. But nothing in principle had changed and the split in the ranks of the Society was to prove irrevocable. Far from withering away as Waine and Cave had hoped, the Action Group was to prosper. What had started out as a ginger group within the MS Society soon became a separate charity in its own right-Action for Research into Multiple Sclerosis (ARMS) -with a social character and constitution distinctively different from that of the Multiple Sclerosis

\footnotetext{
${ }^{160}$ Anon, 'News from Nottingham', account written by a participant for publication in a Branch Newsletter, publication details unknown, copy in SA/MSS/A.57.
}

${ }^{161}$ Ibid.

162 Ibid.

${ }^{163}$ Letter, J J Pritchard to R Cave, 6 April 1976, SA/MSS/A.57. 
Society of Great Britain and Northern Ireland. ${ }^{164}$ In some ways this was to make the eighties just as difficult for the MS Society as either of the two previous decades, especially since ARMS championed the controversial hyperbaric oxygen therapy. But that is another story. ${ }^{165}$

1976 was a pivotal year for the MS Society in another crucial respect-it was to acquire a new Chair. While the Working Party had been gathering evidence, Cave had written in confidence to Sir Ranulph to ask whether he should consider his position as Chairman of the Society. Sir Ranulph assured him that none of the testimony gathered by the Working Party contained any personal criticism of him or of his conduct as Chairman. ${ }^{166}$ As we have already noted, Cave had received warm expressions of support from several members of the Society during the difficult Field affair. The Working Party's Report praised him generously. Nevertheless, Cave chose to resign, giving as his reason that his hearing was deteriorating and he was beginning to find the chairing of meetings difficult. ${ }^{167}$ Angela, Countess of Limerick, graciously stepped down as President of the Society to allow Cave to take over that figurehead position.

The contest for the new Chair was between $\mathrm{Mr}$ Gilbert $\mathrm{H}$ Macdonald, Chair of the South-West London Branch and the Council's candidate, and Dr Alexander $\mathbf{N}$ Strachan of the Action Group. Macdonald represented himself as the candidate of cautious, responsible reform, emphasizing that he was "free from any involvement in past controversies". ${ }^{168} \mathrm{He}$ was duly elected. Macdonald's assumption of the Chair signalled a significant change in the character of the Society's leadership. A pharmacist by training and a businessman by occupation, Macdonald was a senior executive of the Wellcome Foundation. ${ }^{169}$ While Cave might be said to have represented Faith and Establishment, the new Chair's commitments were evidently to the secular values of scientific expertise and modernizing managerialism.

Upon his retirement, Cave could certainly take some satisfaction from the state of the MS Society. Despite its endemic disputes, the Society had grown steadily in numbers, income and influence since its foundation in 1953. In 1976 it had approximately 32,000 members. Moreover, the Society had gained considerable respect and recognition in medical and scientific circles. It was a major funder of research. The suspicion which had, in the fifties and sixties, surrounded the involvement of lay societies in funding biomedicine had been substantially laid to rest. In 1974, the MS Society and the MRC jointly sponsored an international research conference on

\footnotetext{
${ }^{164}$ Robinson, op. cit., note 4 above, describes the differences in character between the two societies, pp. 114-24. ARMS remained active until it ran into financial difficulties in the midnineties. Field continued his work, initially with ARMS support, at the privately funded Naomi Bramson Research Unit, University of Warwick. His diagnostic test did not become generally adopted.

${ }^{165}$ For an analysis of aspects of this controversy, see Nicolson and McLaughlin, op. cit., note 65 above.
}

\footnotetext{
${ }^{166}$ Letter, R Bacon to R Cave, 15 June 1975, SA/MSS/A.57.

${ }^{167}$ Waine resigned at the same time, see $M S$ News, 1976, Christmas, 17.

${ }^{168}$ Election leaflets for both candidates are in the Council Papers, 1976 AGM, SA/MSS/A.5.

${ }^{169}$ Anon., 'A fairly light-hearted profile of our new chairman by someone who knows him fairly well', MS News, 1977, Spring, 9-10.
} 


\section{Malcolm Nicolson and George $W$ Lowis}

multiple sclerosis and Cave addressed the Royal Society of Medicine. ${ }^{170}$ Nevertheless, Cave had found dealing with doctors, scientists and troublesome MS activists somewhat trying. His real satisfactions as Founder and Chair of the Society continued to lie in the areas that had been his particular concerns during his earliest years of involvement with the organization.

In the early seventies the MS Society took over the running of Mary's Mead, a nursing home in Sevenoaks, as a holiday centre for multiple sclerosis sufferers. The home was staffed by the Franciscan Missionary Sisters. In July 1972, Archbishop Cowderoy, Archbishop of Southwark, visited Mary's Mead at Cave's invitation to say Mass. Cave read the prayers and played the piano. He recorded his impressions of the event:

It is impossible, from this bald account, to convey ... how moving was the scene in the front room at Mary's Mead as Archbishop Cowderoy said Mass there. Suffice to say that as he left, I told the Archbishop that the scene there - my Archbishop saying Mass in "my" Holiday Home surrounded by people disabled by MS for whom I had crusaded for so long-was in some ways the culmination of my 19 years work. Archbishop Cowderoy was visibly moved, and clasped my hands with both his. ${ }^{171}$

\section{Conclusions}

Much of the character of the above narrative may be explained in terms of particular features of the Multiple Sclerosis Society of Great Britain and Northern Ireland. We have pointed out how the social characteristics of the Society's leadership led to the adoption and maintenance of hierarchical authority structures. The fact that Cave (and Waine) conceived of MS in spiritual as well as secular terms meant that sometimes the leadership worked according to an agenda which many of the membership did not share. The Executive's overriding concern with respectability, together with the very considerable degree of independence and autonomy which the Society's Medical Advisory Research Committee enjoyed, often made it difficult to respond to the urgent demands of the lay membership.

It would, however, be a mistake to regard the above factors, either individually or collectively, as constituting a complete explanation of why the early decades of the MS Society were so marked by controversy. We would contend that the history of the MS Society and its difficulties indicates that a degree of underlying tension between lay person and professional is structural to modern medicine and health care. In the twentieth century, orthodox medicine achieved a degree of professional authority and dominance hitherto unprecedented. In terms of the technical control of disease, biomedical science has made impressive strides. But its message to the laity remains essentially contradictory, being negative and positive, optimistic and cautious, simultaneously. It promises cures but it must also emphasize the difficulties and limitations of medical research and of medicine itself. Ultimately medicine

\footnotetext{
${ }^{170}$ Typescript of speech, 17 Oct. 1974, SA MSS/B.31; A N Davison et al. (eds), Multiple Sclerosis research: proceedings of a joint conference held by the Medical Research Council and the
} 


\section{The Early History of the Multiple Sclerosis Society}

cannot fulfil, or even adequately respond to, all of the expectations it engenders. The authority of the profession, however great, is thus always and inevitably problematic. There will always be issues upon which that authority is questioned by the interested laity.

Moreover, in the latter half of the twentieth century, with doctors very effectively organized into professional and disciplinary organizations, the interaction of the laity with medical authority was often equally collective. Whereas historians of the nineteenth and early twentieth centuries have rightly stressed the importance of the study of the consultative encounter to the understanding of the medicine of these times, historians of late twentieth-century medicine might also find formative lay/ professional interactions within social organizations, such as the MS Society, in which both the medical profession and the laity are centrally involved. We can also discern, in particular in the origins and character of the Action Group, the impact of the emergence of a non-deferential collective identity amongst the disabled and the chronic sick, which challenged established medical and social attitudes towards their care and treatment.

It is noteworthy also that the pattern of interaction between the laity and the profession within the MS Society was characterized neither by simple confrontation nor co-operation but by complex and shifting configurations. We have seen how Field acted as the spokesman of orthodoxy in the Le Gac case and then, a few years later, allied himself strongly with the Action Group. A similar, if somewhat less dramatic, shift was made by Lumsden, who also sought to cultivate lay support in his difficulties with the Society. Likewise, while the leadership of the Society and the Medical Advisory Research Committee always publicly presented a common front, in private their relationship was sometimes marked by serious differences of opinion and emphasis. Moreover, despite its entrenched position of authority, the Advisory Research Committee did not always have totally unhindered freedom of action. The laity, either the leadership of the MS Society or the interested public as a whole, could affect the way in which the research budget of the Society was spent-if sufficient pressure could be brought to bear on the MARC. The Society's patient alleviation programme, for example, was initiated as a direct result of expressions of concern from the membership, supported by the Executive. It is unlikely, as we have seen, that the Society would have spent so much of its funds on dietary research if this issue had not attracted the attention of large numbers of MS patients.

Having argued that the social tensions that marked the early history of the Multiple Sclerosis Society were not unique to it, we would, nevertheless, also argue that the distinctive pathology of multiple sclerosis was centrally relevant to the character of the controversies we have described. MS patients and their families, living with the actuality or, perhaps even more emotively, the potentiality of serious disability, are understandably anxious and impatient to see rapid advancement in medical science and improvement in the clinical management of their condition. They have a keen interest in the development of therapy, yet, because the course of the disease is often irregular, the success of therapeutic measures is very difficult to assess. Thus an awareness on the part of the historian of the material realities of the disease-its slow and inconstant course, the fact that it strikes young adults but may not 


\section{Malcolm Nicolson and George W Lowis}

necessarily incapacitate them - is indeed centrally relevant to answering the question "why did the tensions underlying much of modern medicine find such a florid expression within the British Multiple Sclerosis Society?" In other words the history of the MS Society was produced by a mutually formative interaction between social and biological phenomena. ${ }^{172}$ What we must conclude is that, far from the body being wholly a product of the play of medical power, as Foucauldian authors have argued, ${ }^{173}$ the material reality of the body can, under the right social circumstances, produce and constitute a genuine resistance to that power. ${ }^{174}$

There has been much interest recently in the history and sociology of the body. But in the case of chronic illness, this has, as we noted above, concentrated largely upon the impact of bodily impairment upon subjective experience or life history. These studies, while invaluable, have thus been curiously individualistic. Likewise those authors who have sought to retain a space for the biomedical model within the sociology of illness have tended to conceive of the interaction between the biological and the social in quite rigidly deterministic terms. Thus Kelly and Field, following Stone, write that "biological facts become social facts because others respond to the person in terms of their physicality". ${ }^{175}$ But as the history of multiple sclerosis exemplifies, one might also argue that bodily impairment can enable social action as persons collectively, and creatively, respond to the challenges of their own physicality. ${ }^{176}$ More generally, we would argue that, at least on occasion, when accounting for the nature of collective social action on matters of health and illness, one must consider specific circumstances of corporeal materiality. This approach should allow the integration of a recognition of the physical effects of disease within a sociology of chronic illness that is neither necessarily individualistic in its starting point nor rigidly biologically deterministic in its theorizing.

\footnotetext{
${ }^{172}$ See also $M$ Nicolson, 'Emergence, resistance and the historiography of medicine', Soc. Stud. Sci., 1996, 26: 863-74.

${ }^{173} \mathrm{D}$ Armstrong, Political anatomy of the body: medical knowledge in Britain in the twentieth century, Cambridge University Press, 1983.

${ }^{174}$ This point is cognate with the political argument of $\mathbf{M}$ Oliver, Understanding disability: from theory to practice, London, Macmillan, 1996, pp 106-7.

${ }^{175}$ M P Kelly and D Field, 'Medical sociology, chronic illness and the body', Sociol. Health Illn., 1996, 18: 241-57; G P Stone, 'Appearance and the self', in A M Rose (ed.), Human behaviour
}

\footnotetext{
and social processes, London, Routledge and Kegan Paul, 1962.

${ }^{176}$ For accounts of sufferers politicized and, indeed, empowered by their multiple sclerosis, see N Davoud, Where do I go from here: the autobiography of a remarkable woman, London, Piatkus, 1985; C Mackie, Me and my shadow: learning to live with multiple sclerosis, London, Aurum, 1999. MS patients may also, of course, react to their illness with demoralization or depression, G E Berrios and J I Quemada, 'Depressive illness in multiple sclerosis: clinical and theoretical aspects of the association', Br. J. Psychiatry, 1990, 156: 10-16.
} 